\title{
AZOLIGANDS AS BRIDGES IN MACROCYCLIC DINICKEL COMPLEXES
}

\author{
Vasile Lozan \\ Institute of Chemistry ASM, Academiei str., 3, Chisinau, MD 2028, R. Moldova \\ e-mail: vasilelozan@gmail.com
}

\begin{abstract}
The coordination chemistry of dinickel macrocyclic hexaamine-dithiophenolate complexes of Robson-type with azoligands is presented in this microreview. All complexes have been characterised by IR-, UV/Vis-spectroscopy, and X-ray crystallography. The bioctahedral transition metal complexes of the type $\left[\left(\mathrm{L}^{6}\right) \mathrm{Ni}_{2}\left(\mu-\mathrm{L}^{\prime}\right)\right]^{+}$exhibit a rich coordination chemistry since the active coordination site $\mathrm{L}^{\prime}$ is accessible for a wide range of exogenous coligands.
\end{abstract}

Keywords: coordination chemistry, structures, azoligands, nickel macrocyclic complexes, amino-thiophenolate ligands.

\section{Introduction}

The coordination chemistry of transition-metal complexes with well-defined binding pockets is currently attracting much interest [1-5]. By adjusting the size and form of the pocket it is often possible to coordinate coligands in unusual coordination modes, to activate and transform small molecules [6] or to stabilize reactive intermediates [7]. Such compounds also allow an interplay of molecular recognition and transition-metal catalysis [8,9] and the construction of more effective enzyme mimics [10]. Consequently, a large number of supporting ligands have been developed that create confined environments about active metal coordination sites. The majority of these ligands form mononuclear compounds, as for instance the calixarenes [11], the cyclodextrins [12,13] and some tripod ligands [14,15]. In contrast, there are only a few ligand systems that impose cagelike structures about polynuclear cores [16-18].

\section{Binucleating thiophenolate macrocycles}

One of the most efficient syntheses of macrobinucleating ligands such as the tetraimine-diphenol $\mathrm{H}_{2} \mathrm{~L}^{1}$ (Fig. 1) involves a Schiff base condensation of 2,6-diformyl-4-methyl-phenol with an aliphatic $\alpha, \omega$-diamine in the presence of a labile first-row transition metal ion. This elegant one-step method provides the ligands in good to excellent yield as their dinuclear metal (II) complexes $\left[\mathrm{M}_{2} \mathrm{LX} \mathrm{X}_{2}\right](\mathrm{X}=$ anion). Since its discovery by Robson and coworker in 1970 [19], this reaction has been successfully applied to a large number of other phenolate-based Schiff bases.

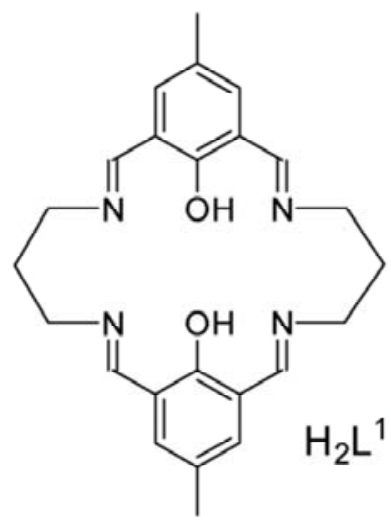

Fig. 1. Structure of the macrobinucleating ligand $H_{2} L^{1}[19]$.

The reader is directed to earlier reviews on macrobicyclic polyaza-phenolate ligands for excellent introductions to this area [20-23]. The synthesis of the free Schiff bases has been described by Schroder et al. [24].

The synthesis of macrocyclic ligands incorporating thiolate donors has also been actively pursued within the past several years, motivated primarily by their ability to model the active site of dinuclear metallo-enzymes [25-27]. An early example incorporating alkyl thiols is the hexadentate $\mathrm{N}_{4} \mathrm{~S}_{2}$ ligand $\mathrm{H}_{2} \mathrm{~L}^{2}$ (Fig. 2) derived from the condensation of bis(1,5-diamine-pentane-3-thiolato)dinickel(II) with formaldehyde and nitroethane in aqueous basic solution [28]. 

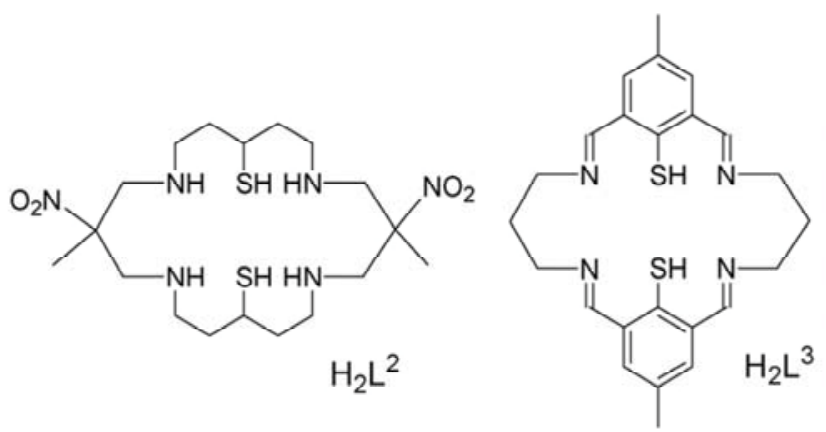

Fig. 2. Structure of macrobinucleating ligands $\mathrm{H}_{2} \mathrm{~L}^{2}[28]$ and $\mathrm{H}_{2} \mathrm{~L}^{3}$ [29].

Concurrently, Brooker et al. had independently developed a robust synthesis of $\mathrm{H}_{2} \mathrm{~L}^{3}$ and this was subsequently detailed in the literature [30]. This approach makes use of the protected thiophenolate precursor S-(2,6-diformyl-4 methylphenyl) dimethylthiocarbamate, whose masking $\mathrm{CO}\left(\mathrm{NMe}_{2}\right)$ group is readily removed in situ by base hydrolysis. The work incorporating the synthesis of the $(2+2)$ thiophenolate Schiff-base macrocyclic complexes can be found in recent reviews by Schroder [24], Brooker [31] and Tamburini and co-workers [32].

\section{Polyamine-dithiophenolate macrocycles}

The reduction of the imine donors is expected to affect the ligating properties of the Schiff-base thiophenolate ligands significantly due to significantly decreased ligand field strength and the sterically more demanding ( $\mathrm{sp}^{3}-$ hybridized) amine functions of the resulting polyamine-dithio-phenolates [33]. In addition, such macrocycles should be hydrolytically more robust than their parent Schiff bases [34-37]. Brooker and co-workers described the first such complex, $\left[\mathrm{Ni}_{2}\left(\mathrm{~L}^{4}\right)\right]\left(\mathrm{ClO}_{4}\right)_{2}$, in 1998 (Fig. 3).
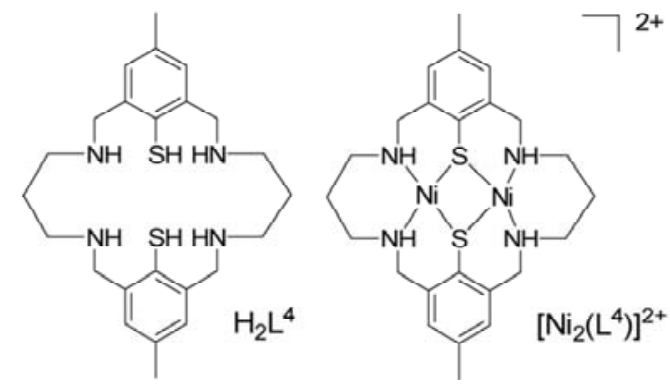

Fig. 3. Structure of $\mathrm{H}_{2} \mathrm{~L}^{4}$ and its dinickel(II) complex [38].

The complex $\left[\mathrm{Ni}_{2}\left(\mathrm{~L}^{4}\right)\right]\left(\mathrm{ClO}_{4}\right)_{2}$ was prepared in good yields by the reduction of $\left[\mathrm{Ni}_{2}\left(\mathrm{~L}^{3}\right)\right]\left(\mathrm{ClO}_{4}\right)_{2}$ with $\mathrm{NaBH}_{4}$ in $\mathrm{MeOH}$ followed by acidic workup [38].

The 24-membered Robson-type hexaaza-dithiophenolate ligand $\mathrm{H}_{2} \mathrm{~L}^{5}$ and its various derivatives have been utilized by Kersting and co-workers as supporting ligands for dinuclear complexes with a bioctahedral $\mathrm{N}_{3} \mathrm{M}\left(\mu-\mathrm{S}_{2}\right)_{2}\left(\mathrm{~L}^{\prime}\right)$ $\mathrm{MN}_{3}$ core structure (Scheme 1).
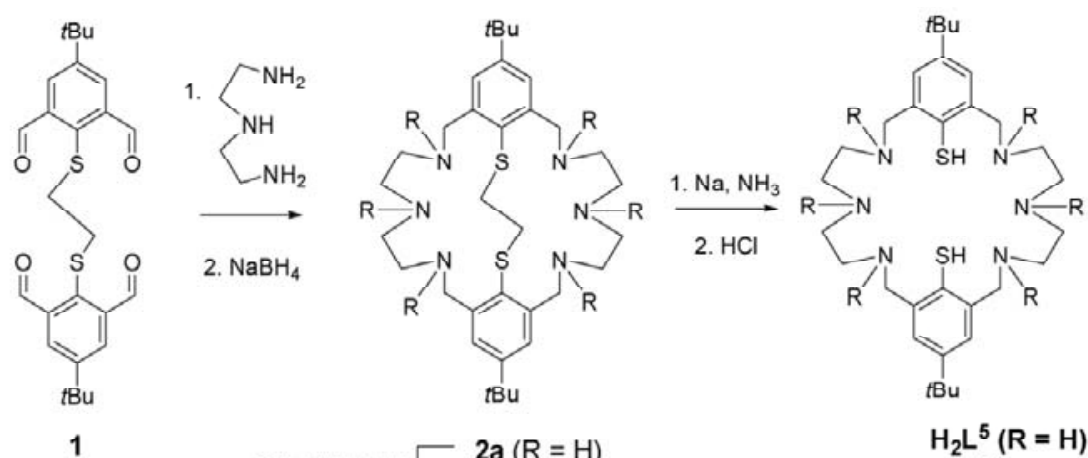

$$
\begin{aligned}
\mathrm{CH}_{2} \mathrm{O} / \mathrm{HCO}_{2} \mathrm{H} \square & 2 \mathrm{a}(\mathrm{R}=\mathrm{H}) \\
& 2 \mathrm{~b}\left(\mathrm{R}=\mathrm{CH}_{3}\right)
\end{aligned}
$$

$\mathrm{H}_{2} \mathrm{~L}^{5}(\mathrm{R}=\mathrm{H})$

$\mathrm{H}_{2} \mathrm{~L}^{6}\left(\mathrm{R}=\mathrm{CH}_{3}\right)$

Scheme 1. Synthesis of $\mathrm{H}_{2} \mathrm{~L}^{5}$ and $\mathrm{H}_{2} \mathrm{~L}^{6}[49,50]$. 
The macrocycle $\mathrm{H}_{2} \mathrm{~L}^{5}$ was prepared by a $[1+2]$ condensation reaction of the tetraaldehyde 1 with 2 equiv. of diethylenetriamine in $\mathrm{EtOH} / \mathrm{CH}_{2} \mathrm{Cl}_{2}$ using medium-dilution conditions followed by two successive reductions with $\mathrm{NaBH}_{4}$ and $\mathrm{Na} / \mathrm{NH}_{3}[39,40]$. The yield of the macrobicycle $2 \mathrm{a}$ is excellent $(>90 \%)$, attributable to the template effect of the bridging ethylene unit which predisposes the four aldehyde groups during the Schiff-base formation step [41-43]. Similar reactions of 1 with ethylenediamine or propylenediamine yielded tricyclic [2+4] macrocycles because these diamines cannot easily span the aldehyde functions of $1[44,45]$. An attractive feature of the macrobicyclic intermediate 2a compared to unprotected thiolate ligands is that its secondary amines are readily alkylated without affecting the masked thiolate functions [46]. Thus, reductive methylation of 2a with formaldehyde and formic acid under EschweilerClarke conditions, followed by deprotection of $2 \mathrm{~b}$ with $\mathrm{Na} / \mathrm{NH}_{3}$ provides the permethylated derivative $\mathrm{H}_{2} \mathrm{~L}^{6}$ in nearly quantitative yield. The $\mathrm{H}_{2} \mathrm{~L}^{7}$ macrocycle ligand without t-Bu-groups was obtain in the same way as $\mathrm{H}_{2} \mathrm{~L}^{6}$, begin from 1,3-dimethyl-benzene.

The ligand $\mathrm{H}_{2} \mathrm{~L}^{6}$ is effective dinucleating ligand towards various divalent metal ions. Complexes of composition $\left[\mathrm{M}_{2}^{\mathrm{II}}\left(\mathrm{L}^{6}\right)\left(\mu-\mathrm{L}^{\prime}\right)\right]^{+}(\mathrm{M}=\mathrm{Mn}, \mathrm{Fe}, \mathrm{Co}, \mathrm{Ni}, \mathrm{Zn}, \mathrm{Cd})$ bearing $\mathrm{Cl}^{-}$and $\mathrm{OAc}^{-}$coligands ( $\left.\mathrm{L}^{\prime}\right)$ (Fig. 4) can be readily obtained by treatment of the free ligands $\mathrm{H}_{2} \mathrm{~L}^{6}$ with two equivalents of the corresponding metal(II) dihalogenides $\left(\mathrm{MCl}_{2}\right)$ or acetates $\left(\mathrm{M}(\mathrm{OAc})_{2}\right)$ in methanolic solution in the presence of a base.
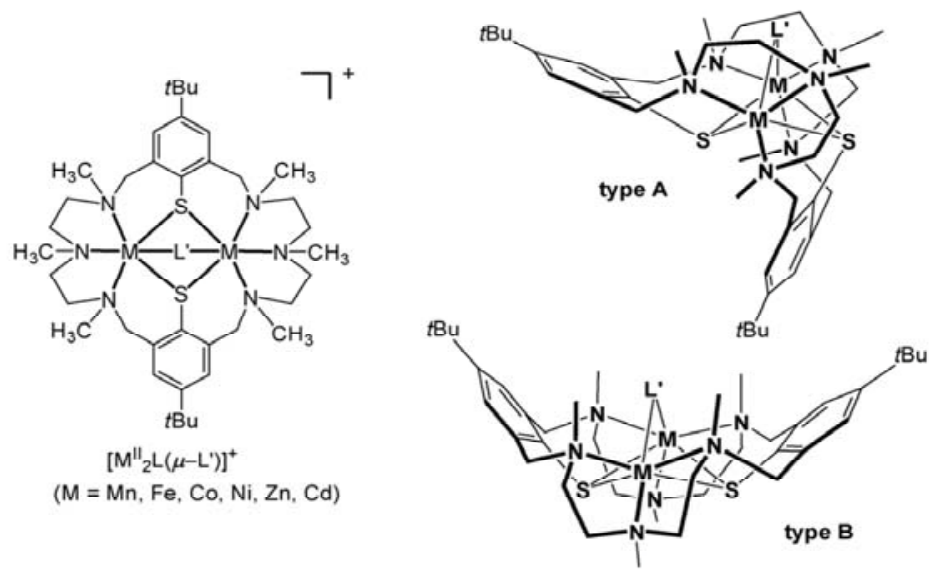

Fig. 4. Cationic $\left[\mathrm{M}_{2}^{\mathrm{II}}\left(\mathrm{L}^{6}\right)\left(\mu-\mathrm{L}^{\prime}\right)\right]^{+}$complexes supported by the ligands $\left(\mathrm{L}^{6}\right)^{2-}$ and schematic representation of their structures $\left(L^{\prime}=\right.$ coligand $)[46,47]$.

Interestingly, the macrocycles can adopt two different conformations A and B (Fig. 4), which are reminiscent of the "partial cone" and "cone" conformations of the calixarenes. A detailed comparison of the individual structures has shown that the conformation of the amino thiophenolates $\left(\mathrm{L}^{6}\right)^{2-}$ is coupled to the size of the coligand $\mathrm{L}^{\prime-}$ and the metal ion radii $[48,49]$. For the complexes of the $3 \mathrm{~d}$ elements the type A conformation is only seen for small monoatomic bridging ligands such as $\mathrm{L}^{-}=\mathrm{OH}^{-}$and $\mathrm{Cl}^{-}$. For large monoatomic coligands (such as $\mathrm{SH}^{-}$) or a multiatom bridging ligand (such as $\mathrm{OAc}^{-}$) the bowl-shaped conformation $\mathrm{B}$ is assumed, the driving force being the more regular octahedral coordination environments about the $\mathrm{M}^{\mathrm{II}}$ ions [50].

The complexes are thus invariably bioctahedral with either a face-sharing or edge-sharing $\mathrm{N}_{3} \mathrm{M}(\mu-\mathrm{SR})_{2}\left(\mu-\mathrm{L}^{\prime}\right)$ $\mathrm{MN}_{3}$ core structure depending on the coordination mode of the coligands. Note that the metal-metal separations $(\mathrm{d}$ $(M \cdots M)$ ) correlate with the bridging mode of the coligands, i.e., $\left(d\left(\mu-L^{\prime}\right)<d\left(\mu_{1,2}-L^{\prime}\right)<d\left(\mu_{1,3}-L^{\prime}\right)\right)$. Some of the complexes feature unusual ligand coordination modes.

\section{Macrocyclic dinickel complexes colligated by molecules containing nitrogen}

So far, our studies have been confined to complexes bearing different coligands, we have now examined the capability of the $\left[\left(\mathrm{L}^{6}\right) \mathrm{Ni}_{2}\right]^{2+}$ fragment to bind as coligands some azocompounds, such as: nitrate, nitrite, azide, hydrazine, pyrazolate (pz), pyridazine (pydz), phthalazine (phtz), and benzoate (OBz). These molecules are known to act as bridging ligands between metal ions, [51] and some of them are biologically important molecules.

Table 1

Synthesized complexes and their labels ${ }^{[a]}$

\begin{tabular}{|l|l|l|}
\hline & {$\left[\left(\mathbf{L}^{6}\right) \mathbf{N i}_{2}\left(\boldsymbol{\mu}-\mathbf{L}^{\prime}\right)\right]^{+}$} & $\mathbf{L}^{\prime}$ \\
\hline $1^{\text {b }}$ & {$\left[\left(\mathrm{L}^{6}\right) \mathrm{Ni}_{2}(\mu-\mathrm{Cl})\right]^{+}$} & Chloride, $\mathrm{Cl}^{-}$ \\
\hline 2 & {$\left[\left(\mathrm{~L}^{6}\right) \mathrm{Ni}_{2}\left(\mu-\mathrm{NO}_{3}\right)\right]^{+}$} & Nitrate, $\mathrm{NO}_{3}^{-}$ \\
\hline
\end{tabular}




\begin{tabular}{|c|c|c|}
\hline 3 & {$\left[\left(\mathrm{~L}^{6}\right) \mathrm{Ni}_{2}\left(\mu-\mathrm{NO}_{2}\right)\right]^{+}$} & Nitrite, $\mathrm{NO}_{2}^{-}$ \\
\hline 4 & {$\left[\left(\mathrm{~L}^{6}\right) \mathrm{Ni}_{2}\left(\mu-\mathrm{N}_{3}\right)\right]^{+}$} & Azide, $\mathrm{N}_{3}^{-}$ \\
\hline 5 & {$\left[\left(\mathrm{~L}^{6}\right) \mathrm{Ni}_{2}\left(\mu-\mathrm{N}_{2} \mathrm{H}_{4}\right)\right]^{2+}$} & Hydrazine, $\mathrm{N}_{2} \mathrm{H}_{4}$ \\
\hline 6 & {$\left[\left(\mathrm{~L}^{6}\right) \mathrm{Ni}_{2}(\mu-\mathrm{pz})\right]^{+}$} & Pyrazolate, $\mathrm{N}_{2} \mathrm{C}_{3} \mathrm{H}_{3}^{-}$ \\
\hline 7 & {$\left[\left(\mathrm{~L}^{6}\right) \mathrm{Ni}_{2}(\mu-\mathrm{pydz})\right]^{2+}$} & Pyridazine, $\mathrm{N}_{2} \mathrm{C}_{4} \mathrm{H}_{4}$ \\
\hline 8 & {$\left[\left(\mathrm{~L}^{6}\right) \mathrm{Ni}_{2}(\mu \text {-phtz })\right]^{2+}$} & Phthalazine, $\mathrm{N}_{2} \mathrm{C}_{8} \mathrm{H}_{6}$ \\
\hline 9 & {$\left[\left(\mathrm{~L}^{6}\right) \mathrm{Ni}_{2}(\mu-\mathrm{OBz})\right]^{+}$} & Benzoate, $\mathrm{C}_{6} \mathrm{H}_{5} \mathrm{CO}_{2}^{-}$ \\
\hline $10^{c}$ & {$\left[\left(\mathrm{~L}^{6}\right) \mathrm{Ni}_{2}(\mu-\mathrm{OAc})\right]^{+}$} & Acetate, $\mathrm{CH}_{3} \mathrm{CO}_{2}^{-}$ \\
\hline 11 & {$\left[\left(\mathrm{~L}^{6}\right) \mathrm{Ni}_{2}(\mu-\mathrm{ttz})\right]^{+}$} & Tetrazole, $\mathrm{HCN}_{4}$ \\
\hline 12 & {$\left[\left(\mathrm{~L}^{6}\right) \mathrm{Ni}_{2}(\mu-\mathrm{mettz})\right]^{+}$} & Methyltetrazole, $\mathrm{CH}_{3} \mathrm{CN}_{4}$ \\
\hline 13 & {$\left[\left(\mathrm{~L}^{6}\right) \mathrm{Ni}_{2}(\mu \text {-phttz })\right]^{+}$} & Phenyltetrazole, $\mathrm{C}_{6} \mathrm{H}_{5} \mathrm{CN}_{4}$ \\
\hline 14 & {$\left[\left(\mathrm{~L}^{6}\right) \mathrm{Ni}_{2}(\mu-\mathrm{bpz})\right]^{+}$} & 4,4'-bipyrazolyl, $\mathrm{C}_{6} \mathrm{H}_{4} \mathrm{~N}_{4}{ }^{2-}$ \\
\hline 15 & {$\left[\left(\mathrm{~L}^{6}\right) \mathrm{Ni}_{2}(\mu-\mathrm{bpdz})\right]^{2+}$} & 4,4'-bipyridazine, $\mathrm{C}_{8} \mathrm{H}_{6} \mathrm{~N}_{4}$ \\
\hline 16 & {$\left[\left(\mathrm{~L}^{6}\right) \mathrm{Ni}_{2}(\mu-\mathrm{bpzb})\right]^{2+}$} & 1,4-bis(4-pyrazolyl)-benzene, $\mathrm{C}_{12} \mathrm{H}_{8} \mathrm{~N}_{4}{ }^{2-}$ \\
\hline 17 & {$\left[\left(\mathrm{~L}^{7}\right) \mathrm{Ni}_{2}(\mu-\mathrm{bpz})\right]^{2+}$} & 4,4'-bipyrazolyl, $\mathrm{C}_{6} \mathrm{H}_{4} \mathrm{~N}_{4}{ }^{2-}$ \\
\hline
\end{tabular}

[a] The complexes were isolated as $\mathrm{ClO}_{4}^{-}$or $\mathrm{BPh}_{4}^{-}$salts. [b] Ref. 46. [c] Ref. [47].

Table 1 lists the synthesized complexes and their lebels. Of these, the chloro- and acetate-bridged complexes 1 and 10 have been reported earlier. Complexes 2-6 and 9 were synthesized by treatment of $1-\mathrm{ClO}_{4}$ with a two- to fivefold excess of the sodium salt of the corresponding anion (or neat hydrazine hydrate in the case of 5) in aqueous methanolic solution. In general, these reactions were complete within a few hours at ambient temperature and produced clear solutions from which, upon addition of an excess of $\mathrm{LiClO}_{4}$, the yellow $\left(4-\mathrm{ClO}_{4}\right)$ or green perchlorate salts $\left(2-\mathrm{ClO}_{4}, 3-\mathrm{ClO}_{4}, 5-\left(\mathrm{ClO}_{4}\right)_{2}, 6-\mathrm{ClO}_{4}\right.$, and 9-- $\left.\mathrm{ClO}_{4}\right)$ of the desired complexes precipitated as microcrystalline solids in good to excellent yields (73-89\%) (Table 1). The dicationic pyridazine and phthalazine derivatives 7 and 8 were prepared in acetonitrile solution, by treatment of $1-\mathrm{ClO}_{4}$ with lead perchlorate in acetonitrile, followed by removal of $\mathrm{PbCl}_{2}(\mathrm{~s})$ by filtration and subsequent addition of the neutral diazine heterocycles. In this way, the diperchlorate salts $7-\left(\mathrm{ClO}_{4}\right)_{2}$ and 8-( $\left(\mathrm{ClO}_{4}\right)_{2}$ were obtained as brown crystals in similarly good yields (Scheme 2).

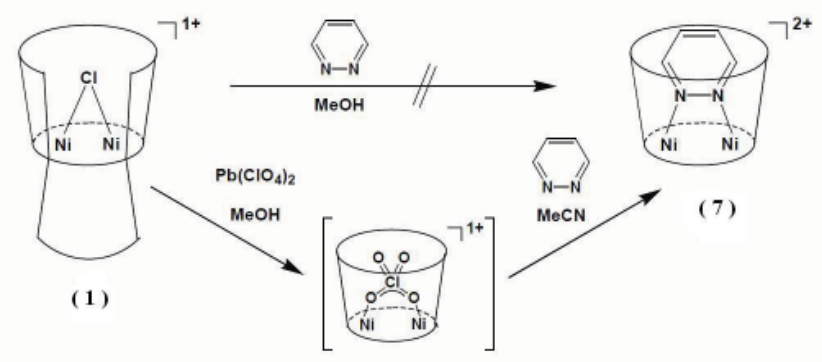

\section{Scheme 2. Synthesis of dinickel complexes with pyridazine.}

In the IR spectra of 2-9 most of the stretching frequencies of the coligands are completely obscured by the absorptions of the $\left[\left(\mathrm{L}^{6}\right) \mathrm{Ni}_{2}\right]^{2+}$ fragment and the counterions $\left(\mathrm{ClO}_{4}^{-}\right.$or $\left.\mathrm{BPh}_{4}^{-}\right)$. Nevertheless some absorptions of the coligands could be detected. In the spectrum of 2, for example, the bands at 1384 and $1277 \mathrm{~cm}^{-1}$ can be assigned to the asymmetric and symmetric stretching modes of a $\mu_{13}$-bridging nitrate ion. [52] Similarly, the band at $1183 \mathrm{~cm}^{-1}$ in the spectrum of 3 reveals the presence of a bridging $\mathrm{NO}_{2}^{-}$group. [53] Likewise, in the spectrum of the azido complex 4 the strong band at $2059 \mathrm{~cm}^{-1}$ implicates a coordinated azide ion. The IR spectrum of hydrazine complex 5 shows sharp absorptions for the asymmetric and symmetric $\mathrm{NH}_{2}$ stretching modes between 3300 and $3250 \mathrm{~cm}^{-1}$, similar to other hydrazine complexes. [54,55] Unfortunately, for 6-8 no characteristic IR absorptions due to the coligands could be detected. Finally, in the spectrum of 9 the most prominent features are the intense bands at 1600 and $1427 \mathrm{~cm}^{-1}$, which can be readily assigned to the asymmetric and symmetric carboxylate stretching modes [56]. The observed values are very similar to those of the acetato-bridged complex 10 , suggesting that the benzoate moiety in 9 is also in the $\mu_{1,3^{-}}$ bridging mode. The UV/Vis spectra of the pale-green nickel complexes are similar but not identical. Each compound displays two weak absorption bands. One appears in the 620 to $670 \mathrm{~nm}$ range, the other one is observed between 1050 and $1180 \mathrm{~nm}$. These absorptions can be attributed to the d-d transitions $v_{2}\left({ }^{3} \mathrm{~A}_{2 \mathrm{~g}}(\mathrm{~F}) \rightarrow{ }^{3} \mathrm{~T}_{1 \mathrm{~g}}(\mathrm{~F})\right)$ and $v_{1}\left({ }^{3} \mathrm{~A}_{2 \mathrm{~g}}(\mathrm{~F}) \rightarrow{ }^{3} \mathrm{~T}_{2 \mathrm{~g}}(\mathrm{~F})\right)$, 
respectively, of an octahedral nickel(II) ( $\left.\mathrm{d}^{8}\right)$ ion. The higher energy features below $400 \mathrm{~nm}$ result from $\pi$ - $\pi *$ transitions within the $\left(\mathrm{L}^{6}\right)^{2-}$ ligand. In summary, the slight differences in the position of the $\mathrm{d}-\mathrm{d}$ transitions indicate that each complex retains its coligand in the solution state. This is also supported by the electrochemical properties described below. All complexes were further characterized by cyclic voltammetry. Figure 5 shows the cyclic voltammogram of the benzoate-bridged complex 9.

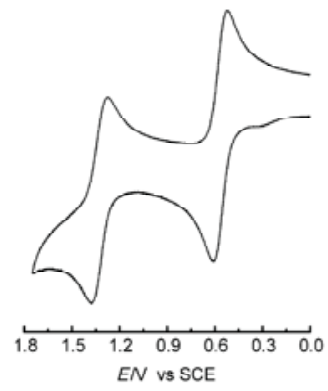

Fig. 5. Cyclic voltammogram of $\left[\left(\mathrm{L}^{6}\right) \mathrm{Ni}_{2}\left(\mu-\mathrm{O}_{2} \mathrm{CPh}\right)\right] \mathrm{ClO}_{4}\left(9-\mathrm{ClO}_{4}\right)$ in $\mathrm{CH}_{3} \mathrm{CN}\left(\mathrm{ca} 1 \times 10^{-3} \mathrm{M}\right)$. scan rate $100 \mathrm{mV} \mathrm{s}^{-1}$.

This complex undergoes two reversible one-electron oxidations at very positive potentials, the $\mathrm{E}_{1 / 2}$ values being $+0.51(\Delta \mathrm{Ep}=0.11 \mathrm{~V})$ and $+1.28 \mathrm{~V}(0.11)$ versus SCE. The two processes are tentatively assigned to the formation of the mixed-valent $\mathrm{Ni}^{\mathrm{II}} \mathrm{Ni}^{\mathrm{III}}$ and $\mathrm{Ni}^{\mathrm{III}} \mathrm{Ni}^{\mathrm{III}}$ species, [57] as indicated in Equation (1).

$$
\left[\left(\mathrm{L}^{6}\right) \mathrm{Ni}_{2}{ }^{\mathrm{III}}\left(\mu-\mathrm{L}^{\prime}\right)\right] \underset{-\mathrm{e}^{-}}{\stackrel{+\mathrm{e}^{-}}{\rightleftharpoons}}\left[\left(\mathrm{L}^{6}\right) \mathrm{Ni}^{\mathrm{III}} \mathrm{Ni}^{\mathrm{II}}\left(\mu-\mathrm{L}^{\prime}\right)\right]^{2+} \underset{-\mathrm{e}^{-}}{\stackrel{+\mathrm{e}^{-}}{\rightleftharpoons}}\left[\left(\mathrm{L}^{6}\right) \mathrm{Ni}_{2}{ }^{\mathrm{II}}\left(\mu-\mathrm{L}^{\prime}\right)\right]^{+}
$$

The cyclic voltammograms of the other dinickel(II) complexes also reveal two redox waves with very positive oxidation potentials. However, the redox waves above about $0.90 \mathrm{~V}$ are all irreversible. Nevertheless, it can be clearly, that the redox potentials of the $\left[\left(\mathrm{L}^{6}\right) \mathrm{Ni}^{\mathrm{II}}{ }_{2}\left(\mu-\mathrm{L}^{\prime}\right)\right]^{\mathrm{n}+}$ complexes depend on the coligand $\mathrm{L}^{\prime}$. The complexes $2-4,6$, and 9 with anionic coligands are all easier to oxidize (by ca. $0.40 \mathrm{~V}$ ) than the complexes 5,7 , and 8 bearing neutral coligands. The lowering of the redox potentials in the former is presumably due to a stabilizing Coulomb attraction between the anionic coligands and the positively charged $\left[\left(\mathrm{L}^{6}\right) \mathrm{Ni}^{\mathrm{III}} \mathrm{Ni}^{1 \mathrm{II}}\right]^{2+}$ species formed upon oxidation. The electrochemical data thus confirm the conclusions drawn from the UV/Vis spectroscopic studies that the $\left[\left(\mathrm{L}^{6}\right) \mathrm{Ni}_{2}\left(\mu-\mathrm{L}^{\prime}\right)\right]^{\mathrm{n}+}$ complexes retain their bioctahedral structures in the solution state.

Herein we demonstrate that all species can be readily accommodated in the binding pocket of $\left[\left(\mathrm{L}^{6}\right) \mathrm{Ni}_{2}\right]^{2+}$. In each case we have obtained single crystals suitable for X-ray structure determinations. Therefore, it has been possible to study in detail the effect of the size and form of the binding pocket of the $\left[\left(\mathrm{L}^{6}\right) \mathrm{Ni}_{2}\right]^{2+}$ fragment on the coordination mode of the coligands and vice versa.

It is appropriate to discuss the structure of the $\left[\left(\mathrm{L}^{6}\right) \mathrm{Ni}_{2}\right]^{2+}$ subunit in 2-9 first. In all new dinickel(II) complexes the macrocycle adopts the conical calixarene-like conformation previously reported for the acetate-bridged complex 10 (Figure 4, type B) $[47,58]$. In this nearly $\mathrm{C}_{2 \mathrm{v}}$-symmetric structure, the two nickel atoms are coordinated in a squarepyramidal fashion by two $f a c-\mathrm{N}_{3}(\mu-\mathrm{S})_{2}$ donor sets of the doubly deprotonated macro-cyclic $\left(\mathrm{L}^{6}\right)^{2-}$. Upon coordination of the exogenous coligands distorted octahedral environments result for the two metal atoms. The structures of the dinuclear subunits are similar but not identical within the series (Scheme 3).

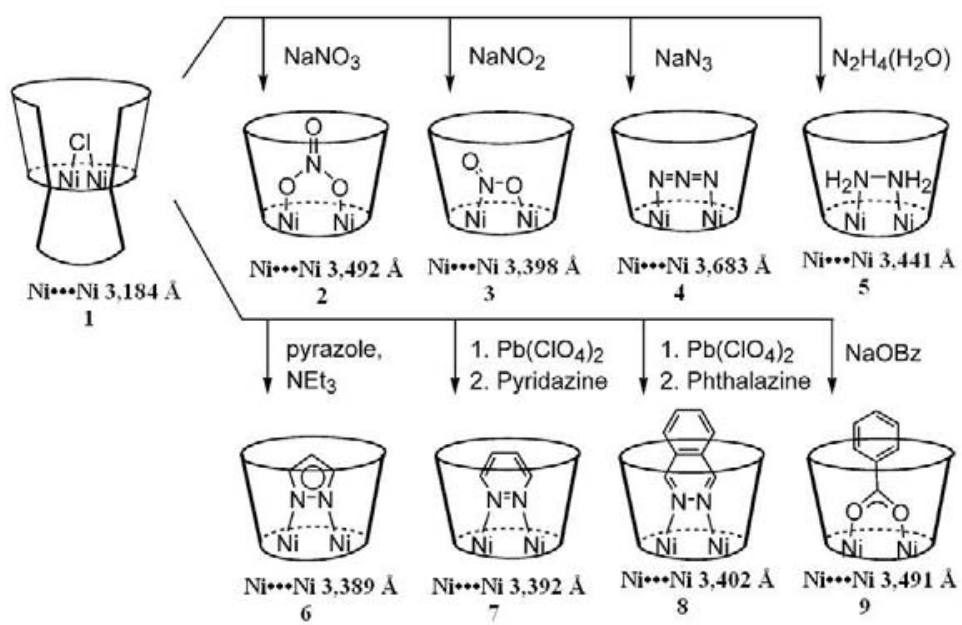

Scheme 3. Synthesis of compounds 2-9 and $\mathrm{Ni} \cdots \mathrm{Ni}$ distances. 
For example, the $\mathrm{Ni} \cdot \mathrm{Ni}$ distance varies from 3,392(1) to 3,683(1) $\AA$. The metal-metal separations correlate with the nature of the bridging ligands. Complexes having multiple atom bridges such as $\mu_{1.3}$-carboxylate display longer $\mathrm{Ni} \cdots \mathrm{Ni}$ distances than complexes with $\mu_{1,2}$-bridges, such as $\mathrm{NO}_{2}^{-}$. In addition the respective metal-ligand bond lengths and angles of the $\left[\left(\mathrm{L}^{6}\right) \mathrm{Ni}_{2}\right]^{2+}$ unit also differ significantly from one structure to other (see Figure 6).

As in previously reported structures of this ligand system (e.g. $\left[\left(\mathrm{L}^{6}\right) \mathrm{Ni}_{2}(\mu-\mathrm{OAc})\right]^{+}, \mathrm{M}=\mathrm{Co}^{\mathrm{II}}, \mathrm{Ni}^{\mathrm{II}}$ and $\mathrm{Zn}^{\mathrm{II}}$, $[47,58]$ the Ni-N bond lengths involving the four benzylic nitrogen donors are invariably longer (by 0,1 $\AA$ ) than the ones comprising the central nitrogen atoms of the linking diethylenetriamine units. The short Ni-N2 and Ni-N5 bonds are therefore not a reflection of a trans influence of the coligand. Rather, the disparities in the metal-nitrogen bond lengths are almost certainly a consequence of the steric constraints of the macrocycle. The average bond lengths and angles, however, are in good agreement with those of other octahedral nickel(II) complexes with mixed thiophenolate/ amine legation [59]. The dimensions of the bowl-shaped cavity of the $\left[\left(\mathrm{L}^{6}\right) \mathrm{Ni}_{2}\right]^{2+}$ fragment can be described by the intramolecular distance between the two opposing aryl ring carbon atoms C4 and C20 (see Figure 7). Interestingly, this distance varies considerably across the present structures. The values range from 8,693 to 9,760 $\AA$. This implies secondary interactions between the guest molecules and the N-alkyl and S-4-tert-butyl-phenyl residues of the distance $\left[\left(\mathrm{L}^{6}\right) \mathrm{Ni}_{2}\right]^{2+}$ subunit. Remarkably, the shortest distance occurs in the benzoato-bridged complex, in spite of the benzoate group being amongst the largest of the investigated guest molecules. For the smaller ionic ligands $\left(\mathrm{NO}_{3}^{-}, \mathrm{NO}_{2}^{-}, \mathrm{N}_{3}^{-}\right.$, $\mathrm{OAc}^{-}$) the $\mathrm{C} 4 \ldots \mathrm{C} 20$ distance is in all cases longer by up to $1 \AA$. The distortions imposed by the benzoate moiety are indicative of attractive van der Waals interactions between the $\mathrm{CH}$ functions of the bowl-shaped host and its guest. As will be shown in more detail below, these secondary host-guest interactions play an important role as they confer unusual binding modes on the coligands.

As can be seen all coligands act as bidentate $\mu_{1, n}$-bridges $(n=2$ or 3$)$. Apparently, in $\left[\left(\mathrm{L}^{6}\right) \mathrm{Ni}_{2}\left(\mu-\mathrm{L}^{\prime}\right)\right]$ complexes of structure type B L' cannot be a single-atom $\left(\mu_{1,1}\right)$-bridging ligand. This seems to be possible only for complexes of the alternative structure type $\mathrm{A}$. In other words, multi-atom bridging ligands induce the $\left[\left(\mathrm{L}^{6}\right) \mathrm{Ni}_{2}\right]^{2+}$ fragment to adopt a structure of the kind $\mathrm{B}$, whereas single-atom bridges such as $\mathrm{Cl}^{-}$or $\mathrm{OH}^{-}$support the conformation of type A. It is also worth mentioning, that the hexaazadithiophenolate ligand supports triply bridged $\mathrm{N}_{3} \mathrm{M}(\mu-\mathrm{SR})_{2}\left(\mu-\mathrm{L}^{\prime}\right) \mathrm{MN}_{3}$ core structures at all. Martell and coworkers, for example, have recently investigated the ligating properties of the analogous hexaazadiphenolate ligand systems. Despite the identical ligand backbones only doubly bridged $\mathrm{N}_{3} \mathrm{M}(\mu-\mathrm{OR})_{2} \mathrm{MN} \mathrm{N}_{3}$ core structures are supported [60]. In addition, these compounds have flat structures in striking contrast to the bowl- or cleftlike structures of the amine-thiophenolate complexes. Another highly significant difference is that the nickel atoms in the phenolate complexes do not bind exogenous coligands, and remain five-coordinate. Similar differences have been noted by Brooker, who compared the coordination chemistries of analogous phenolate and thiophenolate Schiff-bases [31]. The structure differences can be traced to the different hybridizations of the phenolate-oxygen ( $\mathrm{sp}^{2}$, trigonal-planar) and the thiophenolate-sulfur atoms ( $\mathrm{sp}^{3}$, tetrahedral). The former macrocycles tend to enforce a planar $\mathrm{M}(\mu-\mathrm{OR})_{2} \mathrm{M}$ core structure, while the latter feature a bent $\mathrm{M}_{2}(\mu-\mathrm{SR})_{2}$ structure, which can be spanned more easily by the coligands.
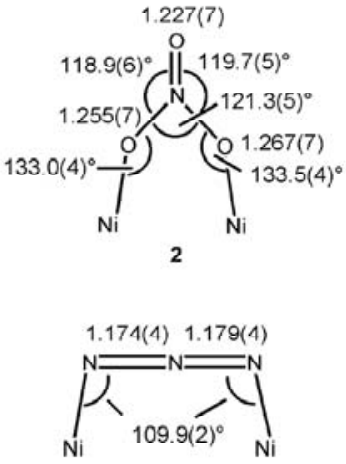

4

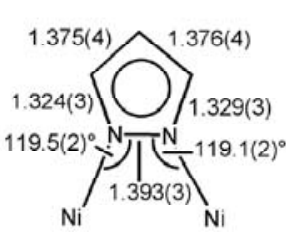

6

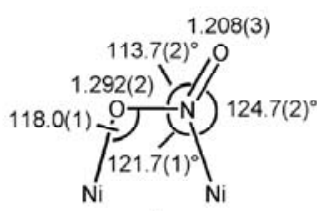

3

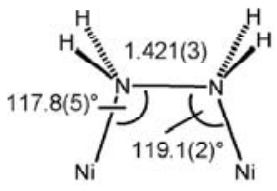

5

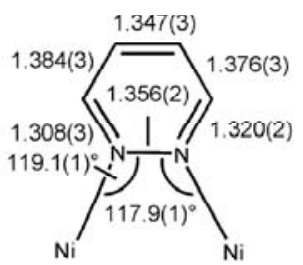

7
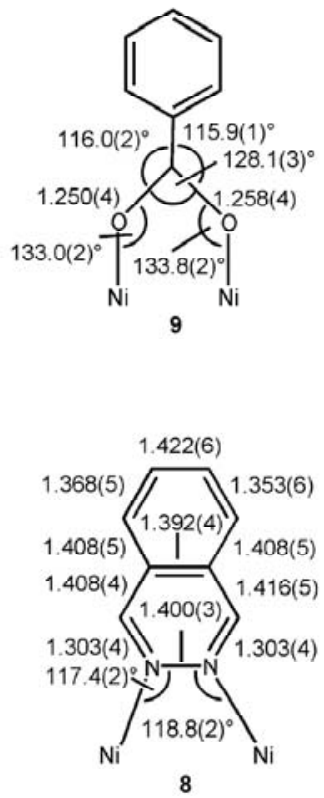

Fig. 6. Binding modes, bond lengths $[\AA \AA]$, and angles $\left[^{\circ}\right]$ of the coligands in 2-9. 
In the following the binding modes of the coligands are described in detail. As can be seen in Figure 7, the nitrate ion in 2 is coordinated in a symmetrical $\mu_{1,3}$-fashion. This is a typical coordination mode of this anion [61] and it has been observed previously in other nitrato-bridged complexes [62,63]. The average Ni-O bond length $(2,071(4)$ $\AA$ ) is significantly longer than in the $\mu_{1,3}$-carboxylato-bridged species 9 and 10, employing that the Ni-nitrate bonds are weaker than the Ni-carboxylate bonds. This nicely corroborates with the results of the binding studies presented below, which reveal that the nitrate group is readily replaced by carboxylate anions, but not vice-versa. The planar $\mathrm{NO}_{3}^{-}$group aligns almost parallel with an adjacent phenyl ring. It is 3,30 to 3,44 $\AA$ from the mean plane of this phenyl ring. This is indicative of an intramolecular $\pi-\pi$ stacking interaction [64]. (Figure 7, cation 2).

The nitrite ion can bridge two metal ions in several ways [51, 65-67]. In the present case, the $\mu_{1,2^{-}}(\mathrm{N}, \mathrm{O}-$ bound $\left.\mathrm{NO}_{2}^{-}\right)$and the $\mu_{1,3}$-modes $\left(\mathrm{O}, \mathrm{O}\right.$-bound $\left.\mathrm{NO}_{2}^{-}\right)$are of relevance. The symmetrical $\mu_{1,3}$-binding motif seems to be geometrically feasible in view of the observed $\mu_{1,3}$-nitrate function in 2 , but the crystal structure reveals the bridging $\mu_{1,2}$-nitro-form. This is presumably due to a more "relaxed" structure of the $\left[\left(\mathrm{L}^{6}\right) \mathrm{Ni}_{2}\right]^{2+}$ fragment in the latter mode of coordination. This is also supported by the fact that the octahedral Ni centers in 3 are much less distorted than in 2.

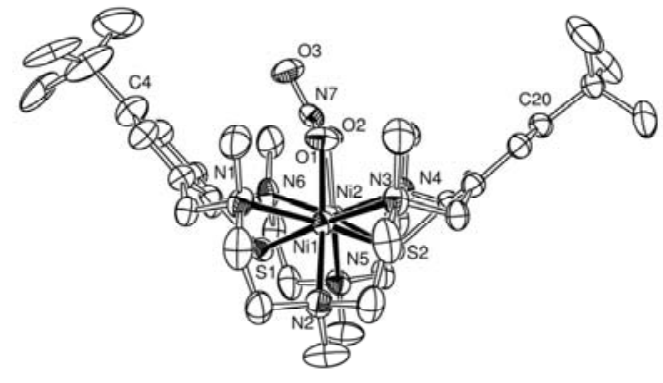

2

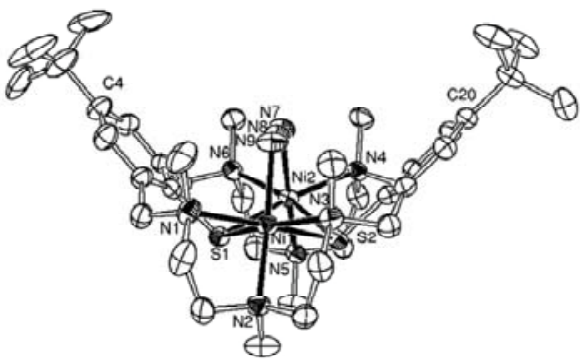

4

Fig. 7. Molecular structure of the cation 2 and 4 in the crystal.

The large numbers of dinuclear nickel complexes with azide linkages exists in the literature [68-70]. This linear triatomic anion can join two Ni centers in an end-on $\left(\mu_{1,1}-\mathrm{N}_{3}\right)$ or an end-to end motif $\left(\mu_{1,3}-\mathrm{N}_{3}\right)$. The latter is seen in the present structure. Of note are the Ni-N-N angles of 109,9 (2) (which are remarkably obtuse for a $\mu_{1,3}$-bridging azide ion) in combination with the planarity of the $\mathrm{Ni}-\mathrm{N}_{3}-\mathrm{Ni}$ assembly (torsional angle $\tau=0^{\circ}$ ). This clearly shows that the binding pocket of the $\left[\left(\mathrm{L}^{6}\right) \mathrm{Ni}_{2}\right]^{2+}$ complex allows for the accommodation of anionic guest molecules in unusual coordination modes. A similar effect has been observed by McKee and Nelson. They were able to stabilize a nearly linear $\mathrm{Ni}-\left(\mu_{1,3}-\mathrm{N}_{3}\right)-\mathrm{Ni}$ linkage in the cavity of a dinuclear nickel cryptate complex [71].

The hydrazine complex 5 provides an example for an unusual conformation of a small inorganic molecule. It is known that free hydrazine exist predominantly, in the gauche conformation at room temperature (dihedral angle $\tau \sim 100^{\circ}$ ) [72]. This conformation is also most commonly seen in dinuclear hydrazine complexes [73]. In the present complex the $\mathrm{N}_{2} \mathrm{H}_{4}$ ligand can only adopt the cis (ecliptic) conformation $\left(\tau \sim 3,7^{\circ}\right)$. To the best of our knowledge, such a coordination mode is without precedence in dinuclear transition-metal hydrazine complexes [74,75], albeit it is documented for mononuclear species [76]. The hydrazine has a N7-N8 bond length of 1,421(3) Å consistent with a N-N single bond. A perchlorate ion is located above the $\mathrm{N}_{2} \mathrm{H}_{4}$ molecule, between the two tert-butyl groups (see Figure 8).

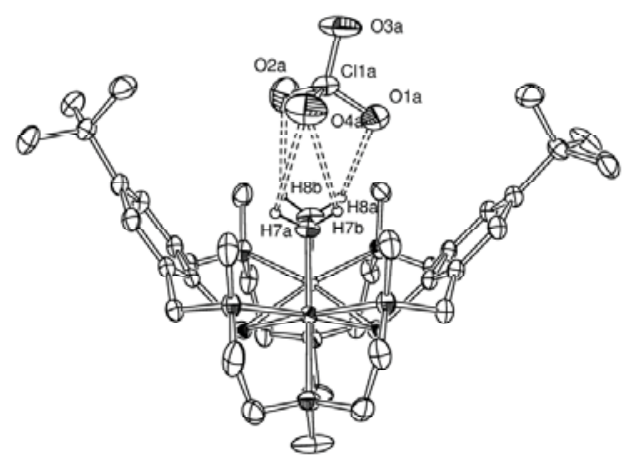

Fig. 8. Intermolecular Hydrogen bonding interactions between hydrazine complex 5 and $\mathrm{a} \mathrm{ClO}_{4}^{-}$counteranion. 
Three of its oxygen atoms form weak hydrogen bonds with the $\mathrm{N}_{2} \mathrm{H}_{4}$ hydrogen atoms (average $\mathrm{NH}^{\cdots} \mathrm{O}$ and $\mathrm{N} \cdots \mathrm{O}$ distances 2,370 and 2,914 $\AA$ ), but on the basis of similar long $\mathrm{NH} \cdots \mathrm{C}$ distances to some of the adjacent aryl carbon atoms (i.e. C2, C6, C16, C18; average value 2,968 $\AA$ ), the presence of repulsive $\mathrm{NH}^{\cdots}{ }^{-\mathrm{C}_{\text {aryl }}}$ van der Waals interactions cannot be excluded. The observed ecliptic $\mathrm{N}_{2} \mathrm{H}_{4}$ conformation would not argue against such an intramolecular steric interaction. It should also be remembered that $\mathrm{NH}_{4}{ }^{+}$ions can form hydrogen bounds with the $\pi$-electrons of phenyl rings [2].

As expected, pyrazolate, pyridazine and phthalazine [77] bind to the $\left[\left(\mathrm{L}^{6}\right) \mathrm{Ni}_{2}\right]^{2+}$ fragment as bidentate bridges through their two ring nitrogens. Consequently, the $\mathrm{Ni} \cdots \mathrm{Ni}$ distances are nearly identical in these three compounds (average value is 3,394(1) $\AA$ ). The average Ni-N(heterocycle) bond lengths to the pyrazolate moiety at 2,041 $\AA$ are shorter than to the pyridazine $(2,128 \AA)$ and phthalazine heterocycles $(2,122 \AA)$, indicating that the pyrazolate anion interacts more strongly with the $\left[\left(\mathrm{L}^{6}\right) \mathrm{Ni}_{2}\right]^{2+}$ subunit than the two neutral diazine molecules. This is further supported by the ligand exchange reactions (see below), which reveal that $\left[\left(\mathrm{L}^{6}\right) \mathrm{Ni}_{2}\right]^{2+}$ binds the pyrazolate anion preferentially over the neutral diazines. The C-N and N-N distances of the $\eta^{2}$-bound heterocycles do not deviate significantly from the distances found in the free heterocycles alone [78] or in other dinuclear nickel(II) complexes of these N-heterocyclic ligand systems [79]. Unlike the pyrazolate and the pyridazine, the phthalazine moiety is tilted out of the Ni1-N7-N8Ni2 plane towards one of the tert-butyl groups, presumably again as a result of hydrophobic interactions between the adjacent $\mathrm{CH}$ groups of the phthalazine moiety and the tert-butyl methyl groups. The pyrazolate and pyridazine structures strongly support these assumptions. These heterocycles are smaller than the phthalazine ring and cannot experience these interactions, because they are too far away from the tert-butyl groups. In 8 , there is also an intermolecular $\pi-\pi$ interaction that occurs between the exposed phthalazine faces of two opposing complexes (Figure 9).

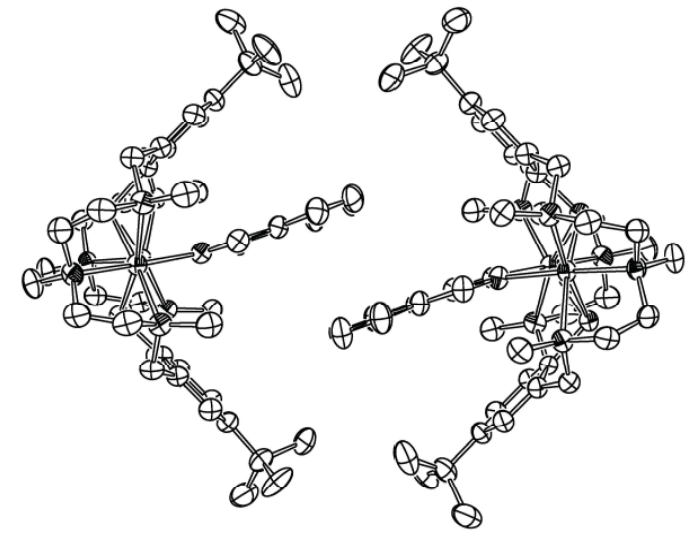

Fig. 9. Intermolecular $\pi$ - $\pi$-stacking interaction between the phthalazine rings of two adjacent complexes 8 .

Last but not least, the benzoate ion in 9 chelates the two $\mathrm{Ni}^{\mathrm{II}}$ ions in a symmetrical $\mu_{1,3}$-fashion, as was previously observed for the acetate group in 10 and already indicated by the IR data. The benzoate phenyl ring is twisted slightly out of the Ni1-O1-C39-O2-Ni2 mean plane such that relatively short contacts between the aryl-hydrogen atoms H44a,b, H42a,b and the hydrogen atoms of the tert-butyl methyl groups $(2,397-3,236 \AA)$ result. The structure is otherwise identical with that of 10 .

We have carried out a series of simple exchange experiments to estimate the relative binding affinities of the coligands. Each reaction was conducted at ambient temperature in a mixed acetonitrile/ethanol (1:1) solvent system using a tenfold excess of the coligand L", according to Equation (2):

$$
\left[\left(\mathrm{L}^{\mathrm{Me}}\right) \mathrm{Ni}_{2}\left(\mu-\mathrm{L}^{\prime}\right)\right]^{\mathrm{n+}}+\mathrm{L}^{\prime \prime} \leftrightarrow\left[\left(\mathrm{L}^{\mathrm{Me}}\right) \mathrm{Ni}_{2}\left(\mu-\mathrm{L}^{\prime \prime}\right)\right]^{\mathrm{n+}}+\mathrm{L}^{\prime}
$$

The reactions were terminated after $5 \mathrm{~h}$ (the time after which no more changes occurred) and the solid products examined by IR spectroscopy, [The reactions could not be monitored by UV/Vis spectroscopy. The spectral changes were too insensitive for some of the reactions.], if the IR spectrum of the isolated solid matched more closely with that of the starting material, $\left[\left(\mathrm{L}^{6}\right) \mathrm{Ni}_{2}\left(\mu-\mathrm{L}^{\prime}\right)\right]^{\mathrm{n}}$, the binding affinity of the coligand $\mathrm{L}^{\prime \prime}$ was estimated to be less than that of $\mathrm{L}^{\prime}$. This was ascertained by successive control experiments, in which the same reactions were run in the reverse direction, but now with $\mathrm{L}^{\prime}$ in tenfold excess over $\left[\left(\mathrm{L}^{6}\right) \mathrm{Ni}_{2}\left(\mu-\mathrm{L}^{\prime \prime}\right)\right]^{\mathrm{n}+}$. This finding could result from the different solubility's of the two species in question. To eliminate this possibility, the reactions were also monitored by infrared spectroscopy in $\mathrm{CH}_{2} \mathrm{Cl}_{2}$ solution. This gave the same ordering of the coligands. In this way the relative binding affinities were determined as follows: pyridazine(7) phthalazine(8) $<$ nitrate(2) $<$ hydrazine(5) $<$ nitrite(3) $<$ pyrazolate(6) $<$ azide(4) $<$ acetate(10) $<$ benzoate( $(9)$.

Two trends are apparent. First, the $\left[\left(\mathrm{L}^{6}\right) \mathrm{Ni}_{2}\right]^{2+}$ complex binds anionic ligands preferentially over neutral species. 
This can be readily explained by the Coulomb attraction between the positively charged $\left[\left(\mathrm{L}^{6}\right) \mathrm{Ni}_{2}\right]^{2+}$ subunit and the negatively charged coligands. Second, the binding affinity of the anions parallels their position in the spectrochemical series [80]. This suggests that strong-field ligands are preferentially bound over weak-field ligands. It is, however, surprising that the benzoate group binds more strongly than the acetate group, in spite of the fact that the acetate is a stronger ligand [81]. We assume that these differences are due to hydrophobic effects, as was already indicated by the crystal structure of 9 . This shows that the secondary host-guest interactions also contribute to the stability of the complexes.

\section{Macrocyclic dinickel complexes colligated by tetrazolate ligands}

In view of the biological and medicinal importance of azoles [82], we considered it worth-while to prepare further complexes of this type to gain more insight into the binding of these compounds towards the $\left[\left(\mathrm{L}^{6}\right) \mathrm{Ni}_{2}\right]^{2+}$ fragment. Here we describe the synthesis and characterization of three novel dinickel complexes bearing tetrazolate ligands and explore their structural features. A survey of the literature reveals that little is known of such coordination compounds [83].

The tetrazolate ligands have been shown to exhibit a rich variety of coordination modes [83]. As shown in Scheme 4 the tetrazolate can either coordinate by means of one, two, three or four endocyclic nitrogen atoms. The actual type of coordination depends on the electronic and steric characteristics of the substituient R and its capability to participate in binding with the metal ion. Additionally, in mixed ligand complexes the coligand also influences the coordination modes of tetrazolates [83]. Based on previous structures of hexaazadithiophenolate complexes $\left[\left(\mathrm{L}^{6}\right) \mathrm{Ni}_{2}\left(\mathrm{~L}^{\prime}\right)\right]^{\mathrm{n}+}$ with $\mathrm{N}$-heterocycles [49] one can assume a coordination of tetrazolate anions through two neighbor-ring nitrogen atoms. In general, the 2,3-bridging mode [84] is favored over the 1,2-bridging mode [85] such that the former is expected for the present compounds.<smiles>[R]c1nnnn1C</smiles><smiles>[R]c1nnn([M])n1</smiles><smiles></smiles><smiles></smiles><smiles></smiles><smiles></smiles><smiles>[R]C1=NN([M])N([M])N1[M]</smiles><smiles></smiles><smiles></smiles>

\section{Scheme 4. Coordination modes of tetrazolate ligands in metal complexes.}

The tetrazolates (5-R-tetrazoles, $\mathrm{R}=\mathrm{H}, \mathrm{Me}, \mathrm{Ph}$; prepared in situ from the free tetrazoles and triethylamine) were found to react smoothly with complex $1-\mathrm{ClO}_{4}$ in methanol over reaction times of several hours to give the green tetrazolate complexes 11-13, which could be isolated as highly crystalline perchlorate salts in yields $>80 \%$ (Scheme 5) [86]. The behaviour of the tetrazolate ligands is thus much like that of carboxylate ligands, which also readily displace the bridging halide ion in $1-\mathrm{ClO}_{4}$. Complexes $11\left[\mathrm{ClO}_{4}\right]-13\left[\mathrm{ClO}_{4}\right]$ are quite stable in solution and could therefore be subjected to salt metathesis with $\mathrm{NaBPh}_{4}$ to generate the corresponding tetraphenylborate salts. The crystal structure determinations described below have shown that this is indeed the case for all three complexes 11-13.

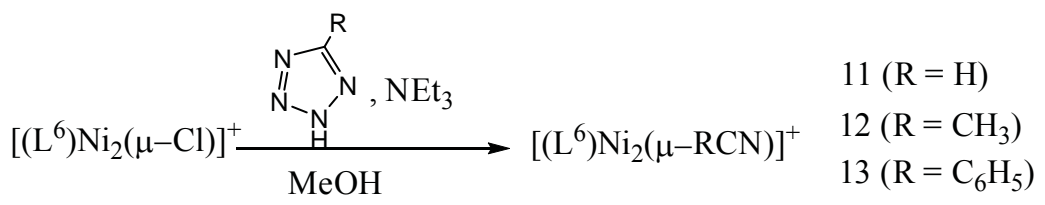

Scheme 5. Synthesis of tetrazolate complexes 11-13. 


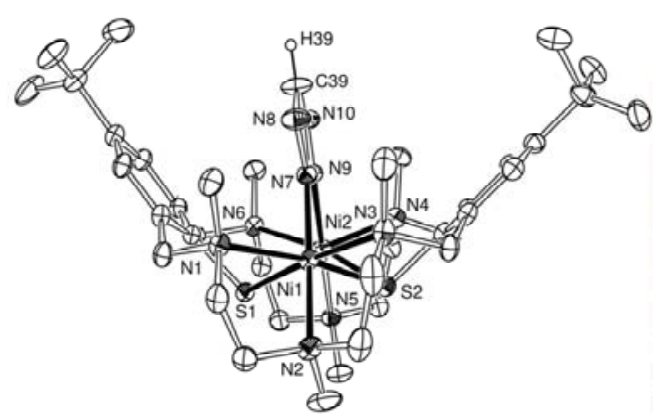

11

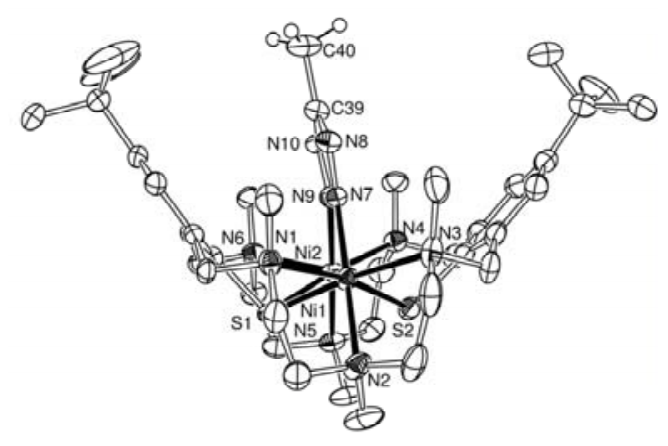

12

Fig. 10. Structure of cations 11 , and 12 in crystals of $11 \cdot\left[\mathrm{BPh}_{4}\right] \cdot \mathrm{MeCN}$, and of $12 \cdot\left[\mathrm{BPh} \mathrm{H}_{4}\right] \cdot 2 \mathrm{MeCN}$ with thermal ellipsoids drawn at $30 \%$ probability. Hydrogen atoms, except $H(39)$ and those bonded to $C(40)$, are omitted for reasons of clarity.

All tetrazolates bind to the $\left[\left(\mathrm{L}^{6}\right) \mathrm{Ni}_{2}\right]^{2+}$ fragment as bidentate bridges through their two ring nitrogen atoms $\mathrm{N}(7)$ and N(9). Consequently, the Ni $\cdots \mathrm{Ni}$ distances are nearly identical in the three compounds (average 3,394(1) $\AA$ ). The macrocycle assumes a bowl-shaped conformation, which is typical for $\left[\left(\mathrm{L}^{6}\right) \mathrm{Ni}_{2}\left(\mathrm{~L}^{\prime}\right)\right]^{+}$complexes when colligated by multi-atom bridging ligands L' [48,49]. All tetrazolate units are essentially planar. The N-N and N-C distances of the tetrazolate rings in 11-13 differ significantly from the corresponding distances of the free 5-R-tetrazoles. Particularly affected are the N(7)-N(9) bonds. Thus, for 1-H-tetrazole and 5-methyl-tetrazole these bonds lengths are 1,295(3) $\AA$ [87] and 1,285(3) $\AA$ [88], much shorter than in 11-13, averaging at 1,354(3) $\AA$. Similar changes were observed for a related tetrazolate complex with 2,3- $\mu$-coordination [84] albeit to a lesser extent. The larger differences in 11-13 presumably relate to the stronger Lewis acidity of the nickel (II) ions. All three N-N bond lengths in 12 are identical within experimental error, while they vary from $1,317(2)$ to $1,367(2) \AA$ in 11 and from $1,317(4)$ to $1,360(4) \AA$ in 13 .

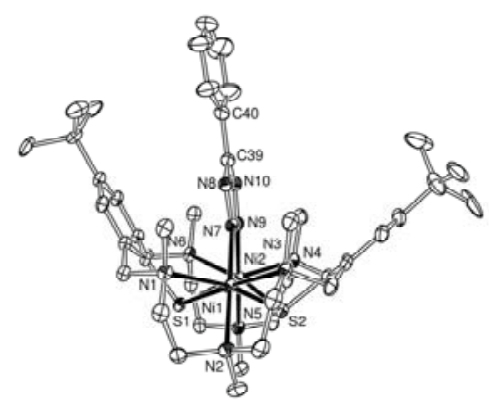

Fig. 11. Structure of cation 13 in crystals of $13 \cdot\left[\mathrm{BPh}_{4}\right] \cdot \mathrm{MeCN}$ with thermal ellipsoids drawn at $30 \%$ probability. Hydrogen atoms are omitted for reasons of clarity.

The average Ni-N(heterocycle) bond lengths are 2,079(2) $\AA(2), 2,067(2) \AA(3)$, and 2,061(3) $\AA$ (4), intermediate between those in the pyrazolato and pyridazine complexes 5 (mean 2,043(2) $\AA$ ) and 6 (mean 2,175(2) $\AA$ ). This suggests that the binding affinity of the tetrazolate anions towards the $\left[\left(\mathrm{L}^{6}\right) \mathrm{Ni}_{2}\right]^{2+}$ subunit is intermediate between that of pyrazolate and the neutral diazine heterocycles. There are no unusual features as far as bond lengths and angles around the Ni atoms are concerned. The average Ni-N ${ }^{\text {amine }}$ and Ni-S distances are 2,239(2) and 2,4870(8) $\AA$, respectively. Similar values have been observed in other $\mathrm{Ni}_{2}$ complexes of $\left(\mathrm{L}^{6}\right)^{2-}$ with $\mathrm{N}$ donor ligands [49]. Overall, the three structures clearly show that the $\left[\left(\mathrm{L}^{6}\right) \mathrm{Ni}_{2}\right]^{2+}$ units can expand their binding pockets sufficiently to accommodate 2,3-bridging tetrazolate ligands.

\section{4,4'-Bipyrazolyl ligands as linker in macrocyclic dinickel complexes}

The coordination chemistry of the potentially quadridentate ligands, 4,4'-bipyrazolyl [89,90] and its derivative [91-94] has been studied in some detail, primarily due to their capability to form porous coordination polymers with potential uses as solid sorbents, ion exchangers or heterogeneous catalysts [95-99]. In this context, a large body of work has been carried out concerning the formation of polypyrazolate based coordination networks with open framework structures [100,101]. It is surprising that such ligands have not yet been used in the construction of discrete polynuclear complexes. The olinuclear $\mathrm{Pd}_{3}$ and $\mathrm{Pd}_{4}$ complexes reported by $\mathrm{Yu}$ et al., may serve as rather rare examples of this class of compounds [102]. 
In view of the strong interest in the targeted design of molecular-based magnetic materials using highspin molecules of higher nuclearity, [103-109] we have initiated a study on the synthesis of complexes in which pairs of exchange coupled $\left[\left(\mathrm{L}^{6}\right) \mathrm{Ni}_{2}\right]$ units are linked by 4,4'-bipyrazole $\left(\mathrm{H}_{2} \mathrm{bpz}\right)$ and 1,4-bis(4-pyrazolyl)-benzene $\left(\mathrm{H}_{2} \mathrm{bpzb}\right)$. The neutral ligand 4,4'-bipyridazine (bpdz) was also included in this study.
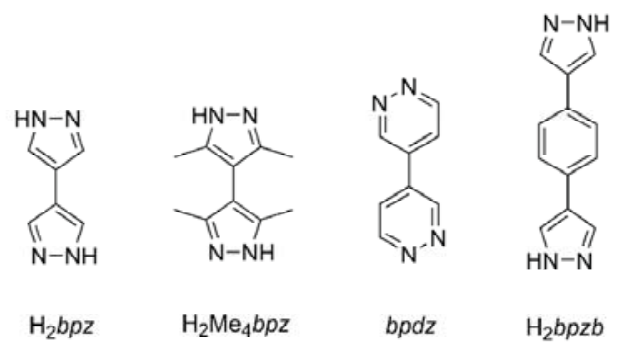

Attempts to link two $\left[\left(\mathrm{L}^{6}\right) \mathrm{Ni}_{2}\right]^{2+}$ units by a $(\mathrm{bpz})^{2-}$ dianion did not meet with any success. Treatment of $\left[\left(\mathrm{L}^{6}\right) \mathrm{Ni}_{2} \mathrm{Cl}\right]$ $\left[\mathrm{ClO}_{4}\right]$ with triethylammonium 4,4-bipyrazolate in methanol in varying molar ratios resulted always in the formation of the green $1: 1$ complex $\left[\left(\mathrm{L}^{6}\right) \mathrm{Ni}_{2}(\mathrm{Hbpz})\right]\left[\mathrm{ClO}_{4}\right]\left(14 \cdot\left[\mathrm{ClO}_{4}\right]\right)$, presumably as a result of the sterically demanding tertbutyl groups. Nickel complexes of the neutral bpdz ligand were found to be inaccessible from $\left[\left(\mathrm{L}^{6}\right) \mathrm{Ni}_{2} \mathrm{Cl}\right]\left[\mathrm{ClO}{ }_{4}\right]$. The substitution reaction succeeded only with the more labile perchlorato complex $\left[\left(\mathrm{L}^{6}\right) \mathrm{Ni}_{2}\left(\mathrm{ClO}_{4}\right)\right]\left[\mathrm{ClO}_{4}\right]$, but again only $1: 1$ complexes formed. Thus, treatment of a dark green acetonitrile solution of $\left[\left(\mathrm{L}^{6}\right) \mathrm{Ni}_{2}\left(\mathrm{ClO}_{4}\right)\right]\left[\mathrm{ClO}_{4}\right]$ with bpdz produced a brown-yellow solution, from which brown crystals of $\left[\left(\mathrm{L}^{6}\right) \mathrm{Ni}_{2}(\mathrm{bpdz})\right]\left[\mathrm{ClO}_{4}\right]_{2}\left(15 \cdot\left[\mathrm{ClO}_{4}\right]_{2}\right)$ could be isolated in $80 \%$ yield [110]. It was clear at this stage that tetranuclear $\mathrm{Ni}_{4}$ complexes would only be accessible with longer bipyrazolyls or with less bulky $\left[\left(\mathrm{L}^{7}\right) \mathrm{Ni}_{2}\right]$ precursor subunits. Indeed, reaction of $\left[\left(\mathrm{L}^{6}\right) \mathrm{Ni}_{2} \mathrm{Cl}\right]\left[\mathrm{ClO}_{4}\right]$ with a 0.5 molar equivalent of (bpzb) ${ }^{2-}$ (prepared in situ from $\mathrm{H}_{2}$ bpzb and $\mathrm{NEt}_{3}$ ) in methanol followed by addition of an excess of $\mathrm{LiClO}_{4}$ and recrystallization from acetonitrile affords the green complex $\left.\left[\left(\mathrm{L}^{6}\right) \mathrm{Ni}_{2}\right)_{2}(\mathrm{bpzb})\right]\left[\mathrm{ClO}_{4}\right]_{2}\left(16 \cdot\left[\mathrm{ClO}_{4}\right]_{2}\right)$ in $76 \%$ yield. Similarly, reaction of $\left[\left(\mathrm{L}^{7}\right) \mathrm{Ni}_{2} \mathrm{Cl}\right]\left[\mathrm{ClO}_{4}\right]$ with half a molar equivalent of $(\mathrm{bpz})^{2-}$ in methanol followed by addition of an excess of $\mathrm{LiClO}_{4}$ furnished the tetranuclear species $\left.\left[\left(\mathrm{L}^{7}\right) \mathrm{Ni}_{2}\right)_{2}(\mathrm{bpz})\right]\left[\mathrm{ClO}_{4}\right]_{2}\left(17 \cdot\left[\mathrm{ClO}_{4}\right]_{2}\right)$ as a dark-green, air-stable solid. Complexes 8 and 9 were also isolated as tetraphenylborate salts.

The IR spectra of compounds display the bands expected for the macrocyclic ligands and counterions, but were not informative with respect to the conformations of the supporting or coligands. Only the band at $3385 \mathrm{~cm}^{-1}$ in the IR spectrum of $14 \cdot\left[\mathrm{BPh}_{4}\right]$ can be attributed to the $\mathrm{N} \cdots \mathrm{H}$ stretching vibration of the protonated pyrazole moiety. The electronic absorption spectra of the nickel complexes display two weak absorption bands around 640 and $1190 \mathrm{~nm}$ typical of octahedral $\mathrm{Ni}^{\mathrm{II}}(\mathrm{S}=1)$ ions.

Single-crystals of $14 \cdot 1,5 \mathrm{MeCN}$ were obtained by slow evaporation of 1:1 acetonitrile/ethanol solution of $14 \cdot\left[\mathrm{BPh}_{4}\right]$. The crystal structure is composed of dinuclear $\left[\left(\mathrm{L}^{6}\right) \mathrm{Ni}_{2}(\mathrm{Hbpz})\right]^{+}$cations, tetraphenylborate anions and acetonitrile molecules of solvent of crystallization. An Ortep plot of the structure of complex 6 is depicted in Figure 12 .

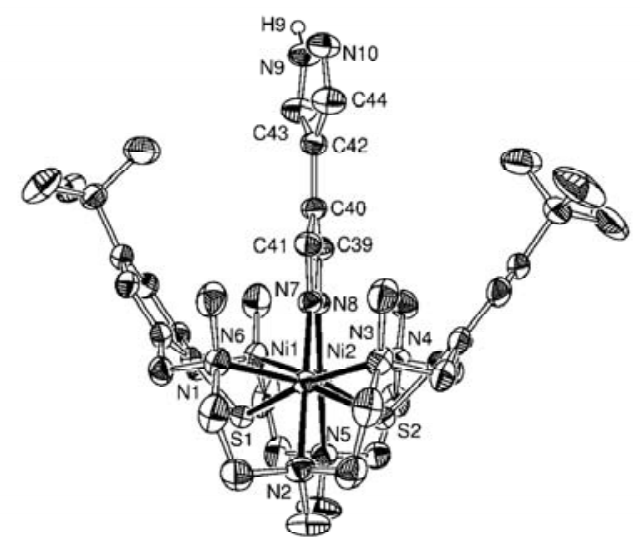

Fig. 12. ORTEP representation of the structure of the $\left[\left(\mathrm{L}^{6}\right) \mathrm{Ni}_{2}{ }_{2}(\mathrm{Hbpz})\right]^{+}$cation in crystals of $14 \cdot\left[\mathrm{BPh}_{4}\right] \cdot 1.5 \mathrm{MeCN}$. Ellipsoids are represented at the $50 \%$ probability level. Hydrogen atoms except H(9) have been omitted for clarity.

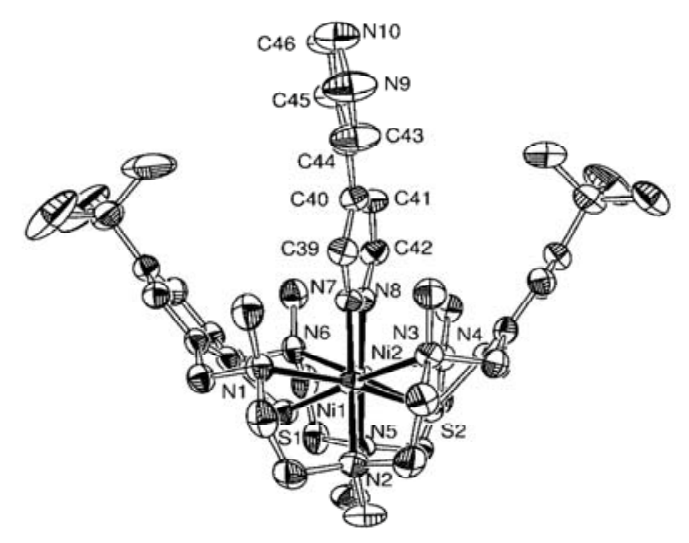

Fig. 13. Structure of the $\left[\left(\mathrm{L}^{6}\right) \mathrm{Ni}^{\mathrm{II}}(\mathrm{bpdz})\right]^{2+}$ dication in crystals of $15 \cdot\left[\mathrm{ClO}_{4}\right]_{2} \cdot 3 \mathrm{MeCN}$ with thermal ellipsoids at the $50 \%$ probability level. Hydrogen atoms are omitted for reasons clarity. 
The bipyrazolato ligand acts only as a bidentate ligand towards one dinuclear $\left[\left(\mathrm{L}^{6}\right) \mathrm{Ni}_{2}{ }^{\mathrm{II}}\right]^{2+}$ unit through the ring atoms $\mathrm{N}(7)$ and $\mathrm{N}(8)$. The atoms $\mathrm{N}(9)$ and $\mathrm{N}(10)$ remain uncoordinated, but the hydrogen atom bonded to $\mathrm{N}(9)$ is involved in a hydrogen bonding interaction with an adjacent acetonitrile solvate molecule [N(9) $\cdots \mathrm{N}(11) 2,975 \AA$ ] . The distance between the $\mathrm{N}$ atom of the acetonitrile and $\mathrm{N}(10)$ is $3,652 \AA$. The corresponding $\mathrm{C}-\mathrm{C}, \mathrm{C}-\mathrm{N}$, and N-N distances of the two five membered rings of the $(\mathrm{bpz})^{2-}$ dianion do not deviate significantly from each other, the largest difference being in the N-N bonds [N(7)-N(8) 1,384(2) $\AA, \mathrm{N}(9)-\mathrm{N}(10) 1,329(2) \AA]$. Note that the two heterocycles are not strictly coplanar. The dihedral angle between the two five-membered rings is $25,6^{\circ}$. The $\mathrm{C}(40)-\mathrm{C}(42)$ bond is of length $1,472(2)$ $\AA$ indicative of a C-C single bond. The $\left[\left(\mathrm{L}^{6}\right) \mathrm{Ni}_{2}\right]^{2+}$ subunits in 14 and the compounds described below are structurally very similar, and the Ni-N and Ni-S distances lie within very narrow ranges. The Ni $\cdots \mathrm{Ni}$ distance is at 3,373(1) $\AA$, which is nearly identical with that in $\left[\left(\mathrm{L}^{6}\right) \mathrm{Ni}_{2}(\mathrm{pz})\right]\left[\mathrm{BPh}_{4}\right][3,389(1) \AA]$ [49]. Overall, this structure clearly shows that the bipyrazolate moiety cannot link two $\left[\left(\mathrm{L}^{6}\right) \mathrm{Ni}_{2}\right]^{2+}$ units. This can be attributed to the steric demand of the $t$-Bu groups which hinder the formation of a tetranuclear complex. This assumption is nicely corroborated by the crystal structure determinations of $17 \cdot\left[\mathrm{BPh}_{4}\right]_{2}$.

Figure 13 shows the structure of the dinuclear $\mathrm{Ni}_{2}{ }_{2}$ complex 15 in crystals of $15 \cdot\left[\mathrm{ClO}_{4}\right] \cdot 3 \mathrm{MeCN}$. Again, the 4,4'-bipyridazine ligand acts only as a bidentate group coordinating to only one bioctahedral $\left[\left(\mathrm{L}^{6}\right) \mathrm{Ni}_{2}\right]^{2+}$ entity through the ring nitrogen atoms $\mathrm{N}(7)$ and $\mathrm{N}(8)$. Metal complexes of 4,4"-bipyridazine have not been reported previously. The average Ni- $\mathrm{N}_{\text {pyridazine }}$ bond length of 2,159(2) $\AA$ is significantly longer than the Ni-N $\mathrm{N}_{\text {pyrazolate }}$ distance in $6[2,043(2) \AA]$, implying that the neutral bipyridazine binds more weakly to the dinuclear $\left[\left(\mathrm{L}^{6}\right) \mathrm{Ni}_{2}\right]^{2+}$ fragment in 15 than does the charged pyrazolato ligand in 14 . A similar behavior has been noted previously for $\left[\left(\mathrm{L}^{6}\right) \mathrm{Ni}_{2}(\mathrm{pydz})\right]^{2+}$ and $\left[\left(\mathrm{L}^{6}\right) \mathrm{Ni}_{2}(\mathrm{pz})\right]^{2+}$ [49]. As in 14, the coordination of the pyridazine ring to the $\mathrm{Ni}^{\mathrm{II}}$ ions results in a slight elongation of the $\mathrm{N}-\mathrm{N}$ bond length $[\mathrm{N}(7)-\mathrm{N}(8)=1,336(2) \AA$ vs. $\mathrm{N}(9)-\mathrm{N}(10)=1,366(2) \AA]$. Likewise, the two six-membered rings are also tilted by $25,2^{\circ}$ with respect to each other. The $\mathrm{Ni} \cdots \mathrm{Ni}$ distance is at $3,401(1) \AA$.

Complex $16 \cdot\left[\mathrm{BPh}_{4}\right]_{2} \cdot 6 \mathrm{MeCN} \cdot 2 \mathrm{H}_{2} \mathrm{O}$ crystallizes in the triclinic space group $\mathrm{P} 1$ with six cocrystallized acetonitrile and two water molecules. The $\left.\left[\left(\mathrm{L}^{6}\right) \mathrm{Ni}_{2}\right)_{2}(\mathrm{bpzb})\right]^{2+}$ complex is centro-symmetric (figure 14). The structure of 16 unambiguously confirms the ability of the deprotonated 1,4-bis(4'-pyrazolyl)-benzene to link two $\left[\left(\mathrm{L}^{6}\right) \mathrm{Ni}^{\mathrm{II}}\right]^{2+}$ units. The four six-coordinate $\mathrm{Ni}$ atoms are arranged in a rectangular fashion, the Ni*Ni distance being 3,349(1) $\AA$ $[\mathrm{Ni}(1) \cdots \mathrm{Ni}(2)]$ and $14,040(1) \AA\left[\mathrm{Ni}(1) \cdots \mathrm{Ni}\left(2^{\prime}\right)\right]$, respectively. Note that the $\mathrm{Ni}_{2}$ pyrazolato planes are coplanar with each other, but that the central aromatic ring is slightly twisted out of this plane $\left(\tau=23,8^{\circ}\right)$. The metal-ligand bond lengths within the $\left[\left(\mathrm{L}^{6}\right) \mathrm{Ni}_{2} \text { (pyrazolato) }\right]^{2+}$ units reveal no anomalities and are very similar to those in 14 . There are no significant intermolecular interactions between the $\mathrm{Ni}_{4}$ complexes. The shortest intermolecular $\mathrm{Ni} \cdots \mathrm{Ni}$ distance is at $7,806(1) \AA$.
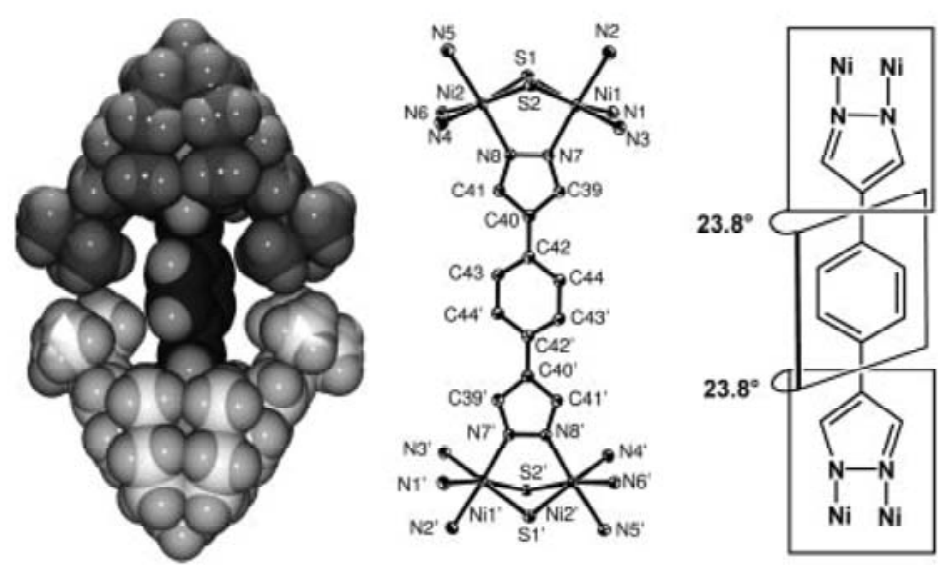

Fig. 14. Left: Van der Waals plot of the $\left.\left[\left(\mathrm{L}^{6}\right) \mathrm{Ni}_{2}\right)_{2}(\mathrm{bpzb})\right]^{2+}$ dication in crystals of $16 \cdot[\mathrm{BPh}]_{2} \cdot 6 \mathrm{MeCN} \cdot 2 \mathrm{H}_{2} \mathrm{O}$. Middle: ORTEP representation of the core structure of 16 with the atom labeling. Scheme. Ellipsoids are represented at the $50 \%$ probability level. Right: Mutual orientation of the $\mathrm{Ni}_{2}$ pyrazolato planes in 16. 

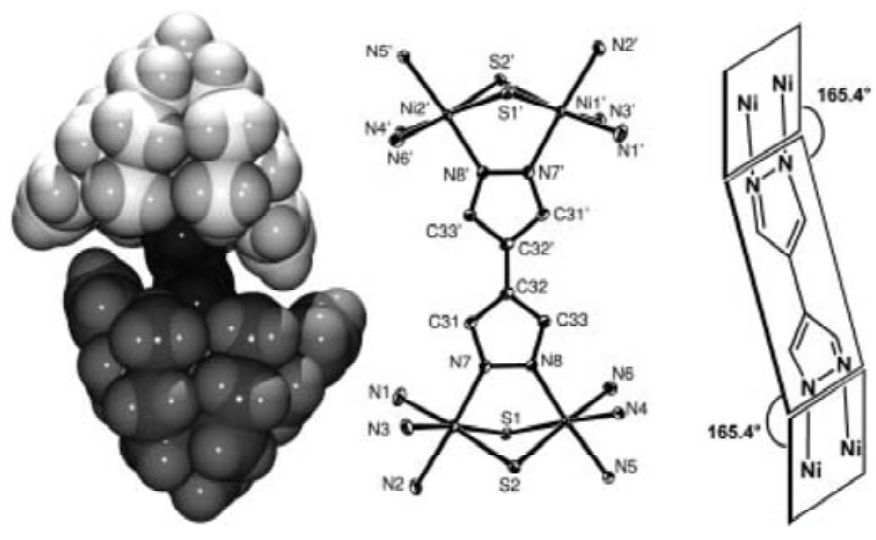

Fig. 15. Left: Van der Waals plot of the $\left[\left\{\left(\mathrm{L}^{7}\right) \mathrm{Ni}^{1 I}{ }_{2}\right\}_{2}(\mu \text {-bipyrazolato })\right]^{2+}$ dication in crystals of $17 \cdot\left[\mathrm{BPh}_{4}\right]_{2} \cdot 2 \mathrm{CH}_{2} \mathrm{Cl}_{2}$.

Middle: ORTEP representation of the core structure of 17 with the atom labeling. Scheme. Ellipsoids are represented at the $50 \%$ probability level. Right: Tilting of the $\mathrm{Ni}_{2}$ pyrazolato planes in 17.

Crystals of $17 \cdot\left[\mathrm{BPh}_{4}\right]_{2} \cdot 2 \mathrm{CH}_{2} \mathrm{Cl}_{2}$ are triclinic, space group P1. Ortep views of the structure of the dication 17 and the central core are provided in Figure 15. Again, 17 exhibits crystallographically imposed inversion symmetry. In striking contrast to 6 , the bipyrazolate moiety in 9 behaves as a tetradentate bridging ligand joining two binuclear $\left[\left(\mathrm{L}^{7}\right)\right.$ $\mathrm{Ni}_{2}$ ] subunits, most likely as a consequence of the absence of the tert-butyl groups in $\left(\mathrm{L}^{7}\right)^{2-}$. The bipyrazolate ligand assumes a planar conformation and the $\mathrm{Ni}_{2} \mathrm{~N}_{2}$ planes are only slightly folded with respect to the bipyrazolato plane (folding angle $165,4^{\circ}$ ). The $\mathrm{Ni} \cdots \mathrm{Ni}$ distance of $3,448(1) \AA$ is the same as that in 6 . The distance d between the centre of the $\mathrm{Ni} \cdots \mathrm{Ni}$ axes of the binuclear subunits amounts to $9,184(1) \AA$, which is significantly smaller than the corresponding distance in 16 . The bond lengths and angles around the $\mathrm{Ni}$ atoms within the $\left[\left(\mathrm{L}^{7}\right) \mathrm{Ni}_{2}\right]^{2+}$ unit reveal no unusual features.

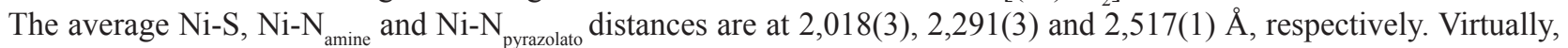
the same distances are seen in 14. A large number of polymeric metal complexes containing bipyrazolato ligands have been structurally characterized [90-95] to the best of out knowledge, 17 is the first discrete species of (bpz) ${ }^{2-}$. Overall, this structure clearly shows that two bioctahedral $\left[\left(\mathrm{L}^{7}\right) \mathrm{Ni}_{2}\right]^{2+}$ units can be linked by bipyrazolate dianions.

\section{Conclusions}

In summary, we presented the synthesis and investigation of the capability of the $\left[\left(\mathrm{L}^{6}\right) \mathrm{Ni}_{2}\right]^{2+}$ complex to bind a range of coligands other than chloride, hydroxide, and acetate has been demonstrated. The structural characterization of new complexes bearing anionic $\left(\mathrm{NO}_{3}^{-}, \mathrm{NO}_{2}^{-}, \mathrm{N}_{3}^{-}\right.$, pyrazolate, benzoate) and neutral coligands (hydrazine, pyridazine, phthalazine) shows that in each case only one of several possible coordination modes is realized. In some cases, the binding pocket confers very unusual coordination modes $\left(\mu_{13}-\mathrm{N}_{3}\right)$ or conformations (ecliptic $\left.\mathrm{N}_{2} \mathrm{H}_{4}\right)$ on the coligands. In other instances, intramolecular host-guest interactions are present. Overall, the crystal structures of tetrazolates, clearly show that the $\left[\left(\mathrm{L}^{6}\right) \mathrm{Ni}_{2}\right]^{2+}$ units can expand their binding pockets sufficiently to accommodate 2,3-bridging tetrazolate ligands.

The synthesis of the first members of a new class of tetranuclear nickel(II) complexes in which pairs of dinuclear $\left[\left(\mathrm{L}^{6}\right) \mathrm{Ni}_{2}\right]^{2+}$ fragments are united by $(\mathrm{bpz})^{2-}$ and $(\mathrm{bpzb})^{2-}$ groups, clearly show that the ease of formation of such cluster depends critically on two factors: (i) the length of the bridging coligand and (ii) the steric demand of the supporting ligand. The dinuclear amine-thiophenolate complexes have a rich coordination chemistry since their active coordination site is accessible for a large variety of neutral and charged coligands ( $\left.\mathrm{L}^{\prime}\right)$.

\section{Acknowledgements}

The author is thankful for Prof. B.Kersting (University of Leipzig, Germany) for providing facilities of work in his research group and the German DAAD for financial support.

\section{References}

[1]. Cram, D.J.; Cram, M.J. in "Container Molecules and Their Guests" (Ed.: J.F.Stoddart). The Royal Society of Chemistry, Cambridge. 1994. 
[2]. a) Vogtle, F. Supramolekulare Chemie, Teubner, Stuttgart. 1992 b) Lehn, J.M. Supramolecular Chemistry, Wiley, Chichester. 1995 c) Steed, J.W.; Atwood, J.L. Supramolecular Chemistry, Wiley, Chichester, 2000.

[3]. Hecht, S.; Frechet, J.M.J. Angew.Chem. 2001, 113, 76-94; Angew.Chem.Int.Ed. 2001, 40, 74-91.

[4]. Hof, F.; Craig, S.L.; Nuckolls, C.; Rebek, J.Jr. Angew.Chem.2002, 114, 1556-1578; Angew.Chem.Int.Ed. 2002, 41, 1488-1508.

[5]. Canary, J.W.; Gibb, B.C. Prog.Inorg.Chem. 1997, 45, 1-83.

[6]. Yandulov, D.V.; Schrock, R.R. Science, 2003, 301, 76-83.

[7]. Rohde, J.-U.; In, J.-H.; Lee, M.H.; Brennessel, W.W.; Bukowski, M.R.; Stubna, A.; Munck, E.; Nam, W.; Que, L.Jr. Science, 2003, 299, 1037-1039.

[8]. a) Reetz, M.T.; Waldvogel, S.R. Angew.Chem. 1997, 109, 870-873; Angew.Chem.Int.Ed.Engl. 1997, 36, 865867; b) Reetz, M.T. Catal.Today. 1998, 42, 399.

[9]. Engeldinger, E.; Armspach, D.; Matt, D. Angew.Chem. 2001, 113, 2594-2597; Angew.Chem.Int.Ed. 2001, 40, 2526-2529.

[10]. a) Seneque, O.; Rager, M.-N.; Giorgi, M.; Reinaud, O. J.Am.Chem.Soc. 2001, 123, 8442-8443; b) Rondelez, Y.; Rager, M.-N. Dupart, A.; Reinaud, O. J.Am.Chem.Soc. 2002, 124, 1334-1340.

[11]. Cameron, B.R.; Loeb, S.J.; Yap, G.P.A. Inorg.Chem. 1997, 36, 5498-5504.

[12]. Stoddart, J.F.; Zarzycki, R. Recl.Trav.Chim.Pays-Bas. 1988, 107, 515-528.

[13]. Wieser, C.; Dieleman, C.B.; Matt, D. Coord.Chem.Rev. 1997, 165, 93-161.

[14]. a) Chaudhuri, P.; Wieghardt, K.; Nuber, B.; Weiss, J. Angew.Chem. 1985, 97, 774-775; Angew.Chem. Int. Ed.Engl.1985, 24, 778-779; b) Chaudhuri, P.; Wieghardt, K. Progr.Inorg.Chem. 1988, 35, 329-436; c) Diebold, A.; Elbouadili, A.; Hagen, K.S. Inorg.Chem. 2000, 39, 3915-3923. d) Tolman, W.B. Acc.Chem.Res. 1997, 30, 227-237.

[15]. a) Kitayima, N.; Tolman, W.B. Prog. Inorg.Chem. 1995, 43, 419-531; b) Trofimenko, S. Scorpionates: The Coordination Chemistry of Polypyrazolylborate Ligands. Imperial College Press, London, UK, 1999; c) Trofimenko, S. Chem Rev. 1993, 93, 943-980; d) Parkin, G. Adv.Inorg.Chem. 1995, 42, 291-393.

[16]. a) Herold, S.; Lippard, S.J. J.Am.Chem.Soc. 1997, 119, 145-156; b) Lee, D.; Lippard, S.J. J.Am.Chem.Soc. 1998, 120, 105-113; c) DuBois, J.; Mizoguchi, T.J.; Lippard, S.J. Coord.Chem.Rev. 2000, 200-202, 443-485.

[17]. Hagadorn, J.R.; Que, L.Jr.; Tolman, W.B. J.Am.Chem.Soc.1998, 120, 13531-13532.

[18]. Fontecha, J.B.; Goetz, S.; McKee, V. Angew.Chem. 2002, 114, 4735-4758; Angew.Chem.Int.Ed. 2002, 41, 45534556.

[19]. Pilkington, N.H.; Robson, R. Aust. J. Chem. 1970, 23, 2225.

[20]. Fenton, D.E.; Vigato, P.A. Chem. Soc. Rev. 1988, 17, 69.

[21]. Vigato, P.A.; Tamburini, S.; Fenton, D. Coord. Chem. Rev. 1990, 106, 25.

[22]. Fenton, D. Chem. Soc. Rev. 1999, 28, 159.

[23]. Okawa, H.; Furutachi, H.; Fenton, D.E. Coord. Chem. Rev. 1998, 174, 51.

[24]. Atkins, A.J.; Black, D.; Blake, A.J.; Marin-Becerra, A.; Parsons, S.; Ruiz-Ramirez, L.; Schroder, M. Chem. Commun. 1996, 457.

[25]. For biological, dithiolate-bridged $\mathrm{Cu} / \mathrm{Cu}$ systems, see; (a) Tsukihara, T.; Aoyama, H.; Yamashita, E.; Tomizaki, T.; Yamaguchi, H.; Shinzawa-Itoh, K.; Nakashima, R.; Yaono, R.; Yoshikawa, S. Science, 1995, 269, 1069; (b) Iwata, S.; Ostermeier, C.; Ludwig, B.; Michel, H. Nature, 1995, 376, 660; (c) Wilmanns, M.; Lappalainen, P.; Kelly, M.; Saver-Eriksson, E.; Saraste, M. Proc. Natl. Acad. Sci. U.S.A. 1995, 92, 11949.

[26]. For biological, dithiolate-bridged Fe/Ni systems, see: (a) Volbeda, A.; Charon, M.-H.; Piras, C.; Hatchikian, E.C.; Frey, M.; Fontecilla-Camps, J.C. Nature, 1995, 376, 660; (b) Volbeda, A.; Garcin, E.; Piras, C.; De Lacey, A.L.; Fernandez, V.M.; Hatchikian, E.C.; Frey, M.; Fontecilla-Camps, J.C. J. Am. Chem. Soc. 1996, 118, 12989; (c) Halcrow, M.A. Angew. Chem. 107 (1995) 1307; (d) Halcrow, M.A. Angew. Chem., Int. Ed. Engl. 1995, 34, 1193.

[27]. For biological, dithiolate-bridged Fe/Fe systems, see: (a) Peters, J.W.; Lanzilotta, W.N.; Lemon, B.J.; Seefeldt, L.C. Science, 1998, 282, 1853; (b) Cammack, R. Adv. Inorg. Chem. 1992, 38, 281.

[28]. Lawrance, G.A.; Maeder, M.; Manning, T.M.; O’Leary, M.A.; Skelton, B.W.; White, A.H. J.Chem. Soc., Dalton Trans. 1990, 2491.

[29]. Atkins, A.J.; Blake, A.J.; Schroder, M. J. Chem. Soc., Chem. Commun. 1993, 1662.

[30]. Brooker, S.; Croucher, P.D.; Roxburgh, F.M. J. Chem. Soc., Dalton Trans. 1996, 3031.

[31]. Brooker, S. Coord. Chem. Rev. 2001, 222, 33.

[32]. Vigato, P.A.; Tamburini, S.; Bertolo, L. Coord. Chem. Rev. 2007, 251, 1311.

[33]. Suh, M.P. in: Sykesed A.G. (Ed.), Advanced Inorg. Chem., Vol. 44, Academic Press, New York, 1997, p. 93.

[34]. Constable, E.C. Metals and Ligand Reactivity, VCH,Weinheim, 1996.

[35]. Adams, H.; Bailey, N.A.; Fenton, D.E.; Good, R.J.; Moody, R.; De Barbarin, C.O.R. J.Chem. Soc., Dalton Trans. 1987, 207. 
[36]. Harding, C.J.; Lu, Q.; Malone, J.F.; Marrs, D.J.; Martin, N.; McKee, V.; Nelson, J. J.Chem. Soc., Dalton Trans. 1995, 1739.

[37]. Brooker, S.; McKee, V. Inorg. Chim. Acta, 1990, 173, 69.

[38]. Brooker, S.; Croucher, P.D.; Davidson, T.C.; Dunbar, G.S.; McQuillan, A.J.; Jameson, G.B. Chem. Commun. 1998, 2131.

[39]. Klingele, M.H.; Steinfeld, G.; Kersting, B. Z. Naturforsch. 2001, 56b, 901.

[40]. Klingele, M.H.; Kersting, B. Z. Naturforsch. 2001, 56b, 437.

[41]. Illuminati, G.; Mandolini, L. Acc. Chem. Res. 1981, 14, 95.

[42]. Diederich, F.; Stang P.J. (Eds.), Templated Organic Synthesis, Wiley-VCH,Weinheim, 2000.

[43]. Busch, D.H.; Stephenson, N.A. Coord. Chem. Rev. 1990, 100, 119.

[44]. Kersting, B.; Steinfeld, G.; Fritz, T.; Hausmann, J. Eur. J. Inorg. Chem. 1999, 2167.

[45]. Kersting, B. Z. Naturforsch. 2000, 55b, 961.

[46]. Kersting, B.; Steinfeld, G. Chem. Commun. 2001, 1376.

[47]. Kersting, B. Angew. Chem. 2001, 113, 4110; Kersting, B. Angew. Chem., Int. Ed. 2001, 40, 3988.

[48]. Journaux, Y.; Glaser, T.; Steinfeld, G.; Lozan, V.; Kersting, B. J.C.S.Dalton Trans. 2006, 1738-1748.

[49]. Hausmann, J.; Klingele, M.H.; Lozan, V.; Steinfeld, G.; Siebert, D.; Journaux, Y.; Girerd, J.J.; Kersting, B. Chem. Eur. J. 2004, 10, 1716.

[50]. Lozan, V.; Kersting, B. Inorg. Chem. 2008, 47, 5386.

[51]. Cotton, F.A.; Wilkinson, G.; Murillo, C.A.; Bochmann, M. Advanced Inorganic Chemistry, $6^{\text {th }}$ ed., Wiley, New York, 1999.

[52]. K. Nakamoto, Infrared and Raman Spectra of Inorganic and Coordination Compounds, 5th ed., VCH-Wiley, New York, 1997.

[53]. K. Wieghardt, H. Siebert, Z. Anorg. Allg. Chem. 1970, 374, 186-190.

[54]. a) K.-H. Linke, F. Durholz, P. Hadicke, Z. Anorg. Allg. Chem. 1968, 356, 113-117; b) K. Brodersen, Z. Anorg. Allg. Chem. 1957, 290, 24-34.

[55]. D. Sellmann, P. Kreutzer, G. Huttner, A. Frank, Z. Naturforsch. B 1978, 33, 1341-1346.

[56]. H. Lang, K. Kohler, L. Zsolnai, Chem. Ber. 1995, 128, 519-523.

[57]. B. Kersting, D. Siebert, Inorg. Chem. 1998, 37, 3820-3828.

[58]. a) Kersting, B.; Steinfeld, G. Inorg.Chem.2002, 41, 1140-1150;

[59]. a) Brooker, S. Coord.Chem Rev.,2001, 222, 33-56; b) Brooker, S.; Croucher, P.D.; Davidson, T.C.; Dunbar, G.S.; Beck, C.U.; Subramanian, S. Eur.J.Inorg.Chem. 2000, 169-179.

[60]. a) Kong, D.; Martell, A.E.; Motekaitis, R.J.; Reibenspies, J.H. Inorg.Chim. Acta, 2001, 317, 243-251; b) Kong, D.; Martell, A.E.; Reibenspies, J.H. Inorg.Chim. Acta, 2002, 333, 7-14; c) Gao, J.; Martell, A.E.; Reibenspies, J.H. Inorg.Chim. Acta, 2002, 329,122-128; d) He, H.; Martell, A.E.; Motekaitis, R.J.; Reibenspies, J.H. Inorg. Chem, 2000, 39, 1586-1592.

[61]. Kleywegt, G.J.; Wiesmeyer, W.G.R.; Van Diel, G.J.; Driessen, W.L.; Reedijk, J.; Noordik, J.K. J.Chem. Soc. Dalton Trans. 1985, 2177-2184.

[62]. Luo, H.; Luo, J.-M.; Fanwick, P.E.; Stowell, J.G.; Green, M.A. Inorg.Chem. 1999, 38, 2071-2078.

[63]. Hausberr-Primo, L.; Hegetschweiler, K.; Ruegger, H.; Odier, L.; R.D.Hancock, R.D.; Schmalle, H.W.; V.Gramlich, V. J.Chem.Soc.Dalton Trans.1994, 1689-1701.

[64]. Hunter, C.A. Chem.Soc.Rev., 1994, 25, 101-109.

[65]. Hitchman, M.A.; Rowbottom, G.L. Coord.Chem.Rev. 1982, 42, 55-132.

[66]. Sieker, A.; Blake, A.J.; Johnson, B.F.G. J.Chem.Soc. Dalton Trans. 1996, 1419-1427.

[67]. Goodgame, D.M.L.; Hitchman, M.A.; Marsham, D.F. J.Chem.Soc.A. 1971, 259-264.

[68]. Pierpont, C.G.; Hendrickson, D.N.; Duggan, D.M.; Wagner, F.; E.K.Barefield, E.K. Inorg.Chem. 1975, 14, 604610.

[69]. Chaudhuri, P.; Guttmann, M.; Ventur, D.; Wieghardt, K.; Nuber, B.; Weiss, J. J.Chem.Soc.Chem. Commun. 1985, 1618-1620.

[70]. Ribas, J.; Escuer, A.; Monfort, M.; Vicente, R.; Cortes, R.; Lezama, L.; Rojo, T. Coord.Chem.Rev. 1999, 193195, 1027-1068.

[71]. a) Harding, C.J.; Mabbs, F.E.; MacInnes, E.J.; McKee, V.; Nelson, J. J.Chem.Soc.Dalton Trans. 1996, 32273230; b) Escuer, A.; Harding, C.J.; Dussart, Y.; Nelson, J.; McKee, V.; Vicente, R. J.Chem.Soc.Dalton Trans. 1999,223-227.

[72]. Holleman, A.F.; Wieberg, E. Lehrbuch der Anorganischen Chemie, 91.-100. ed., Walter de Gruyter, Berlin 1985, p.557-559.

[73]. a) Sellmann, D.; Kunstmann, H.; Knoch, F.; Mill, M. Inorg.Chem. 1988, 27, 4183-4190; b) Sellmann, D.; Soglowek, W.; Knoch, F.; Moll, M. Angew.Chem. 1989, 1010, 1244-1245; Angew.Chem.Int.Ed. Engl. 1989, 28 , 1271-1272. 
[74]. a) Henderson, R.A.; Leigh, G.J.; Pickett, C.J. Adv.Inorg.Chem.Radiochem. 1983, 25, 197-292; b) Sutton, D. Chem. Rev. 1993, 93, 995-1022.

[75]. a) Sellmann, D.; Engl, K.; Heinemann, F.W.; Sieler, J. Eur.J.Inorg. Chem. 2000, 1079-1089. b) Matsumoto, K.; Koyama, T.; Koide, Y. J.Am.Chem.Soc. 1999, 121, 10913-10923; c) Matcukawa, S.; Kuwata, S.; Ishii, Y.; Hidai, M. J.Chem.Soc. Dalton Trans. 2002, 2737-2746.

[76]. a) Blum, L.; Williams, I.D.; Schrock, R.R. J.Am.Chem.Soc. 1984, 106, 8316-8317. b) Murray, R.C.; Schrock, R.R. J.Am.Chem.Soc. 1985, 107, 4557-4558.

[77]. Reeijk, J. in Comprehensive Coordination Chemistry, Vol.2, (Eds.: Wilkinson, G.; Gillard, R.D.; McCleverty J.A.), Pergamon Press, New York, 1987, p.73-98.

[78]. Gilchrist, T.L. Heterocyclic Chemistry, Longman Scientific \&Technical, Essex, 1987.

[79]. a) Barrios, A.M.; Lippard, S.J. J.Am.Chem.Soc. 2000, 122, 9172-9177; b) Barrios, A.M.; Lippard, S.J. Inorg. Chem. 2001, 40, 1250-1255.

[80]. Greenwood, N.N.; Earnshaw, A. Chemie der Elemente, VCH, Weinheim, 1988, p. 1210.

[81]. From the $\mathrm{pKa}$ values of the corresponding acids $[\mathrm{pKa}(\mathrm{BzOH})=4.22, \mathrm{pKa}(\mathrm{AcOH})=4.75]$, the acetate ion is a stronger base than the benzoate group, and hence a stronger s-donor ligand (it has a higher affinity for the proton), see: Isaacs, N. Physical Organic Chemistry, 2nd ed., Addison Wesley Longman, Essex, 1996.

[82]. Comprehensive Heterocyclic Chemistry II, Vol. 3, 4, (Eds. Katritzky, A.R.; Rees, C.W.; Scriven E.F.V), Pergamon Press, Oxford, New York 1996

[83]. a) Gaponik, P.N.; Voitekhovich, S.V.; Ivashkevich, O.A. Russ.Chem.Rev. 2006, 75, 507-539; b) Sadimenko, A.P. Adv.Heterocycl.Chem. 2002, 83, 117-187; c) Moore, D.S.; Robinson, S.D. Adv.Inorg.Chem. 1988, 32, 171-239; d) Popov, A.P. Coord.Chem.Rev., 1969, 4, 463-474.

[84]. a) John, E.O.; Willet, R.D.; Scott, B.; Kirchmeier, R.L.; Shreeve, J.M. Inorg.Chem. 1989, 28, 893-897; b) John, E.O.; Kirchmeier, R.L.; Shreeve, J.M. Eur. J.Solid State Inorg. Chem. 1992, 29, 873-885; c) Shao, Z.-H.; Luo, J.; Cai, R.-F.; Zhou, X.-G.; Weng, L.-H.; Chen, Z.-H. Acta Crystallogr. 2004, E60, m225-m227; d) Dinca, M.; Han, W.S.; Liu, Y.; Dailly, A.; Brown, C.M.; Long, J.R. Angew.Chem. 2007, 119, 1441-1444; Angew.Chem.Int.Ed., 2007, 46, 1419-1422; e) Tao, J.; Ma, Z.-J.; Huang, R.-B.; Zheng, L.-S. Inorg.Chem. 2004, 43, 6133-6135.

[85]. a) Palopoli, S.F.; Geib, S.J.; Rheingold, A.L.; Brill, T.B. Inorg.Chem. 1988, 27, 2963-2971; b) Bhandari, S.; Mahon, M.F.; Molloy, K.C.; Palmer, J.S.; Sayers, S.F. J.Chem.Soc., Dalton Trans. 2000, 1053-1060; c) Dinca, M.; Yu, A.F.; Long, J.R. J.Am.Chem.Soc. 2006, 128, 8904-8913.

[86]. Lozan, V.; Voitekovich, V.S.; Gaponik, P.N.; Ivashkevich, O.A.; Kersting, B. Z. Naturforsch. B. 2008, 63b, 496502.

[87]. Goddard, R.; Heinemann, O.; Kruger, C. Acta Crystallogr. 1997, C53, 590-592.

[88]. Ohno, Y.; Akutsu, Y.; Arai, M.; Tamura, M.; Matsunaga, T. Acta Crystallogr. 1999, C55,1014-1016.

[89]. Trofimenko, S. J.Org. Chem. 1964, 29, 3046-3049.

[90]. Boldog, I.; Sieler, J.; Chernega, A.N.; Domasevitch, K.V. Inorg.Chim.Acta 2002, 338, 69-77.

[91]. Kruger, P.E.; Fallon, G.D.; Moubaraki, B.; Murray, K.S. J.Chem.Soc.,Chem. Commun. 1992, 1926-1927

[92]. a) Ponomarova, V.V.; Komarchuk, V.V.; Boldog, I.; Chernega, A.N.; Sieler, J.; Domasevitch, K. Chem.Commun. 2002, 436-437; b) Boldog, I.; Rusanov, E.B.; Sieler, J.; Blaurock, S.; Domasevitch, K.V. Chem.Commun. 2003, 740-741; c) Rusanov, E.B.; Ponomarova, V.V.; Komarchuk, V.V.; Stoeckli-Evans, H.; Fernandez-Ibanez, E.; Stoeckli, F.; Sieler, J.; Domasevitch, K.V. Angew.Chem. 2003, 115, 2603-2605; Angew.Chem.Int.Ed. 2003, 42, 2499-2501.

[93]. Zang, J.-P.; Horike, S.; Kitagawa, S. Angew.Chem. 2007, 119, 907-910; Angew.Chem.Int.Ed. 2007, 46, 889892.

[94]. He, J.; Yin, Y.-G.; Wu, T.; Li, D.; Huang, X.-C. Chem.Commun. 2006, 2845-2847.

[95]. a) Eddaoudi, M.; Moler, D.B.; Li, H.; Chen, B.; Reineke, T.M.; O’Keeffe, M.; Yaghi, O.M. Acc.Chem.Res. 2001, 34, 319-330; b) Eddaoudi, M.; Kim, J.; Wachter, J.B.; Chae, H.K.; O’Keeffe, M.; Yaghi O.M. J.Am.Chem.Soc. 2001, 123, 4368-4369; c) Rowsell, J.L.C; Millward, A.R.; Park, K.S.; Yaghi, O.M. J.Am.Chem.Soc. 2004, 126, 5666-5667; d) Barton, T.J.; Bull, L.M.; Klemperer, W.G.; Loy, D.A.; McEnaney, B.; Misono, M.; Monson, P.A.; Pez, G.; Scherer, G.W.; Vartuli, J.C.; Yaghi, O.M. Chem. Mater. 1999, 11, 2633-2656.

[96]. Rao, C.N.R.; Natarajan, S.; Choudhury, A.; Neeraj, S.; Ayi, A.A. Acc.Chem.Res. 2001, 34, 80-87.

[97]. Moulton, B.; Zaworotko, M.J. Chem.Rev. 2001, 101, 1629-1658.

[98]. Kitagawa, S.; Noro, S.; Nakamura, T. Chem.Commun. 2006, 701-707.

[99]. Kitagawa, S.; Kitaura, R.; Noro, S. Angew.Chem. 2004, 116, 2388-2430; Angew.Chem.Int.Ed. 2004, 43, 23342375.

[100]. Boldog, I.; Rusanov, E.B.; Chernega, A.N.; Sieler, J.; Domasevitch, K.V. Angew.Chem. 2001, 113, 3543-3546; Angew.Chem.Int.Ed. 2001, 40, 3435-3438.

[101]. Domasevitch, K.V.; Boldog, I. Acta Crystallogr., Sect. C, 2005, 61, 373-376. 
[102]. Yu, S.Y.; Huang, H.-P.; Liu, S.-H.; Jia, Q.; Li, Y.-Z.; Wu, B.; Sei, Y.; Yamaguchi, K.; Pan, Y.-J.; Ma, H.-W. Inorg. Chem. 2005, 44, 9471-9488.

[103]. Magnetism: Molecules to Materials (Eds.: J. S. Miller, J. S.; Drillon M.), Wiley-VCH, Weinheim, 2001.

[104]. Coronado, E.; Delhaes, P.; Gatteschi, D.; Miller J.S. (Eds.), Molecular magnetism: From Molecular Assemblies to Devices, NATO ASI Series, Kluwer, Dordrecht, The Netherlands, 1995, vol. 321.

[105]. Watton, S.P.; Fuhrmann, P.; Pence, L.E.; Caneschi, A.; Cornia, A.; Abbati, G.L; Lippard, S.J. Angew. Chem. 1997, 109, 2917-2919; Angew. Chem. Int. Ed. Engl. 1997, 36, 2774-2776.

[106]. Larionova, J.; Gross, M.; Pilkington, M.; Andres, H.; Stoeckli-Evans, H.; H. U. Güdel, H.U.; Decurtins, S. Angew. Chem. 2000, 112, 1667-1672; Angew. Chem. Int. Ed. 2000, 39, 1605-1609.

[107]. Dearden, A.L.; Parsons, S.; Winpenny, R. E. P.Angew. Chem. 2001, 113, 155-158; Angew.Chem. Int. Ed. 2001, 40, 151-154.

[108]. Demeshko, S.; Leibeling, G.; Dechert, S.; Meyer, F. Dalton Trans. 2006, 3458-3465.

[109]. Kersting, B.; Steinfeld, G.; Siebert, D. Chem. Eur. J. 2001, 7, 4253-4258.

[110]. Lozan, V.; Solntsev, P.; Domasevitch, K.V.; Kersting, B. Eur. J. Inorg. Chem., 2007, 3217-3226. 